\title{
Cysteine aminoethylation enables site-specific glycosylation analysis of recombinant human erythropoietin using trypsin
}

Steffen Lippold, ${ }^{\dagger}$ Alexander Büttner, $\phi$ Matthew S.F. Choo, ${ }^{\Psi}$ Michaela Hook,, Coen J. de Jong, ${ }^{\dagger}$ Terry Nguyen-Khuong, ${ }^{\Psi}$ Markus Haberger, ${ }^{+}$Dietmar Reusch, $\phi$ Manfred Wuhrer, ${ }^{\dagger}$ Noortje de Haant,*

† Center for Proteomics and Metabolomics, Leiden University Medical Center, Albinusdreef 2, 2333 ZA Leiden, The Netherlands

ф Pharma Technical Development, Roche Diagnostics GmbH, Nonnenwald 2, 82377 Penzberg, Germany $\Psi$ Bioprocessing Technology Institute, Agency for Science Technology and Research, 20 Biopolis Way \#06-01, Singapore 138668

*E-mail: ndehaan@sund.ku.dk 


\section{Contents}

S-1 Supporting Information - Materials and Methods............................................................................ 4

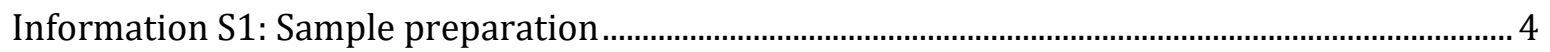

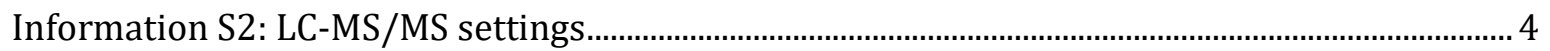

Information S3: Data analysis.......................................................................................................... 5

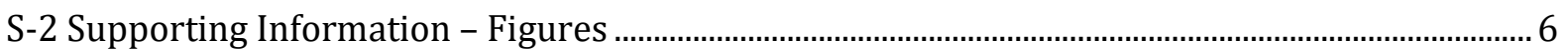

Figure S1: Visualization of the glycopeptide data evaluation workflow. …....................................... 6

Figure S2: Glycopeptide assignments by MS2 of a tryptic rhEPO digest with HCD

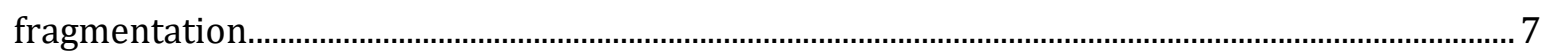

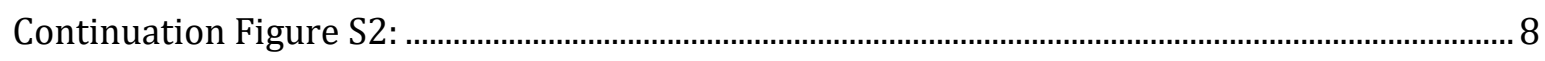

Figure S3: Base peak chromatogram of a representative tryptic EPO digest upon cysteine

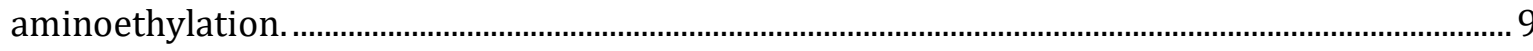

Figure S4: MS1 and MS2 data for cysteine 160 containing peptides used for the assessment of 2-bromoethylamine alkylation and tryptic digestion efficiencies. .................................................. 10

Figure S5: 2-bromoethylamine alkylation selectivity for YLLEAK peptide.................................... 11

Figure S6: 2-bromoethylamine alkylation selectivity for VNFYAWK peptide................................ 12

Figure S7: 2-bromoethylamine alkylation selectivity for MEVGQQAVEVWQGLALLSEAVLR

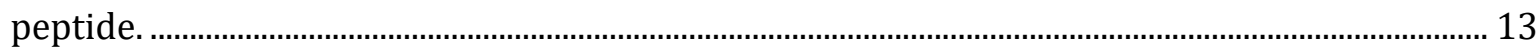

Figure S8: 2-bromoethylamine alkylation selectivity for TITADTFR peptide................................ 14

Figure S9: 2-bromoethylamine alkylation selectivity for VYSNFLR peptide................................. 15

Figure S10: 2-bromoethylamine alkylation selectivity for LYTGEAC* peptide. ............................. 16

Figure S11: MS2 assignment of non-glycosylated variants of tryptic (A) Asn24 and (B) Asn38 peptides upon cysteine aminoethylation....................................................................................... 17

Figure S12: MS2 assignment of the non-glycosylated, missed cleaved and overalkylated Asn24

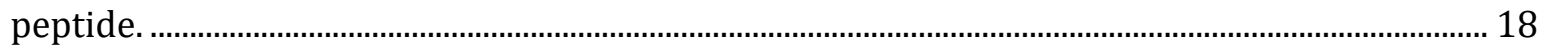

Figure S13: Examples for isomer separation obtained for rhEPO glycopeptides by RP-LC-

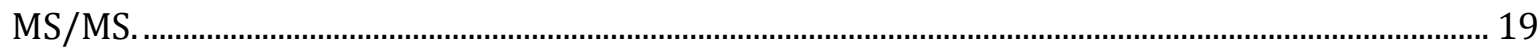

Figure S14: MS2 data of glycoforms which were not reported for rhEPO previously................. 21

Figure S15: Asn24 GluC non-glycosylated variant with cleavage adjacent to the glycosylation

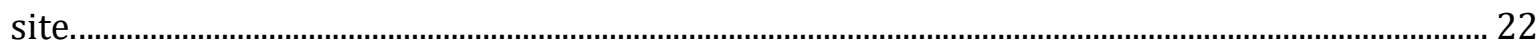

Figure S16: Tryptic rhEPO Asn47 deamidation site. ………............................................................ 23

Figure S17: Tryptic rhEPO Met54 oxidation site.............................................................................. 24

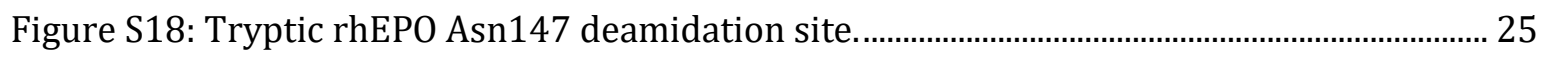

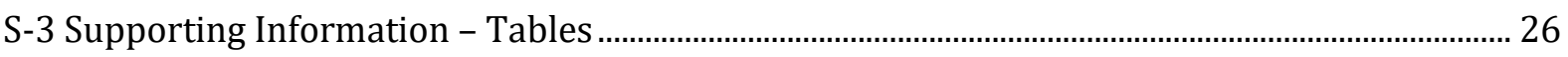

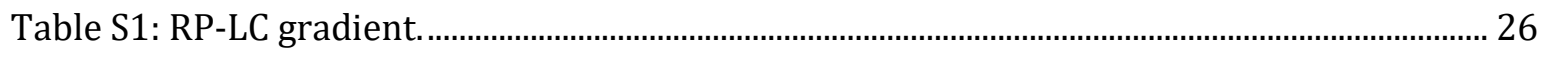

Table S2: Expected tryptic EPO peptides upon cysteine aminoethylation containing at least 3

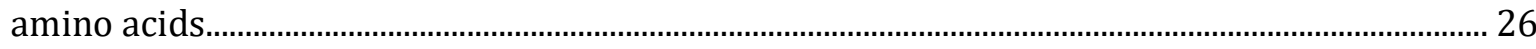


Table S3: Assessment of alkylation and tryptic digestion efficiency of aminoethylated cysteine

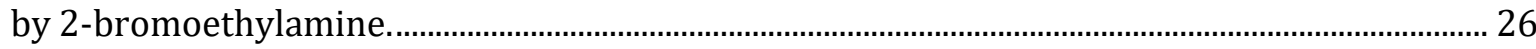

Table S4: Assessment of alkylation specificity of 2-bromoethylamine............................................ 27

Table S5: Overview of assigned peptide moieties for GluC derived and tryptic rhEPO

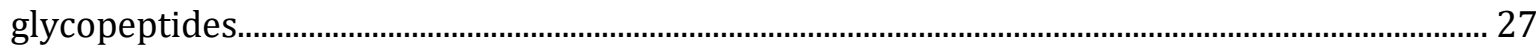

Table S6: Relative abundances of rhEPO glycopeptide cleavage products. ……………………..... 28

Table S7: $N$ - and $O$-glycoforms assigned in the tryptic rhEPO digest on different glycosylation sites. All analytes were curated and quantified in LacyTools. ........................................................... 29

Continuation Table S7: .......................................................................................................................... 30

Continuation Table S7: ................................................................................................................... 31

Table S8: Overview of the detected non-glycosylated variants of rhEPO glycosylation sites. . 31

Table S9: Overview of tryptic peptide moieties used for the relative quantification of Asn47 deamidation, Met54 oxidation and Asn147 deamidation................................................................... 32

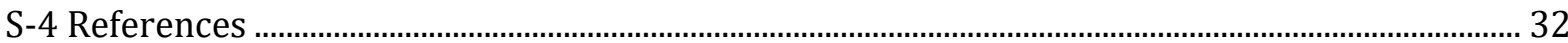




\section{S-1 Supporting Information - Materials and Methods}

\section{Information S1: Sample preparation}

For each sample, $250 \mu \mathrm{g}$ of rhEPO were mixed with denaturation buffer $(0.4 \mathrm{M}$ Tris, $8.0 \mathrm{M}$ guanidinium hydrochloride, $\mathrm{pH} 8.5)$ in a final volume of $300 \mu \mathrm{L}$. Next, $10 \mu \mathrm{L}$ of DTT $(0.1 \mathrm{~g} / \mathrm{mL}$, resulting in $20 \mathrm{mM}$ ) were added and the samples were incubated for $60 \mathrm{~min}$ at $50{ }^{\circ} \mathrm{C}$. For cysteine alkylation, samples were either carboxymethylated by the addition of $10 \mu \mathrm{L}$ iodoacetic acid $(0.33 \mathrm{~g} / \mathrm{mL}$, resulting in $60 \mathrm{mM})$ and incubation at room temperature for $30 \mathrm{~min}$ in the dark, or aminoethylated by the addition of $10 \mu \mathrm{L} 2$-bromoethylamine hydrobromide (Sigma-Aldrich, Steinheim, Germany, $0.59 \mathrm{~g} / \mathrm{mL}$, resulting in $60 \mathrm{mM}$ ) and incubation for $60 \mathrm{~min}$ at $60^{\circ} \mathrm{C}$ (slightly adapted from elsewhere ${ }^{1}$ ). Upon alkylation, a buffer exchange into $450 \mu \mathrm{L}$ of digestion buffer (50 mM ammonium bicarbonate, pH 7.8) was performed using NAP-5-gel filtration columns (Sephadex G-25 Pharmacia). Finally, carboxymethylated rhEPO was digested with GluC (Roche, enzyme:protein $1: 20,25^{\circ} \mathrm{C}$ ) and aminoethylated rhEPO with trypsin (Roche, enzyme:protein $1: 100,37^{\circ} \mathrm{C}$ ) for $16-18 \mathrm{~h}$.

For initial experiments and LC-MS/MS measurements with HCD fragmentation, a slightly different digestion protocol was used. In this case, $100 \mu \mathrm{g}$ of rhEPO were mixed in a final volume of $100 \mu \mathrm{L}$ ammonium bicarbonate buffer, $\mathrm{pH}$ 8.5. For reduction, $2 \mathrm{mM}$ DTT were added and the samples incubated for $30 \mathrm{~min}$ at $60^{\circ} \mathrm{C}$. Afterwards, $6 \mathrm{mM}$ 2-bromoethylamine were added and the samples incubated for $60 \mathrm{~min}$ at $60^{\circ} \mathrm{C}$. Finally, $6 \mathrm{mM}$ DTT were added to the sample. For digestion, sequencing grade trypsin (Promega) was added in a ratio enzyme:protein 1:100. For the initial experiments, no buffer-exchange or clean-up was performed.

\section{Information S2: LC-MS/MS settings}

The measurements for the comparison of tryptic and GluC derived glycopeptides were performed on the LTQ Orbitrap Velos. MS1 resolution was set to 30000 and the AGC target to 1000000 . For MS2, the 5 most intense parent ions were fragmented and an isolation window of $2.2 \mathrm{~m} / \mathrm{z}$, a maximum injection time of $500 \mathrm{~ms}$ and an AGC target of 100000 was applied. The initial test experiments for tryptic EPO glycopeptides were performed on the Q Exactive HF-X. MS1 information were also obtained for $m / z$ 200-2000 in positive ion mode. The resolution was set to 60000 and the AGC target to 1000000 . MS2 experiments with stepped HCD fragmentation were performed with a normalized collision energy of $26,28,30 \%$, an isolation window of $2.2 \mathrm{~m} / \mathrm{z}$ and a maximum injection time of $100 \mathrm{~ms}$. The resolution was set to 15000 and the AGC target to 100000 . 


\section{Information S3: Data analysis}

Raw data were inspected and visualized in Thermo Xcalibur (v2.2). Byonic software (Protein Metrics Inc.) was used for annotation of MS2 spectra. The settings were set to a precursor ion mass tolerance of $10 \mathrm{ppm}$ and product ion tolerance of $20 \mathrm{ppm}$. Fixed modifications were set for cysteines (aminoethylation or carboxymethylation) and aminoethylated cysteine was added as cleavage site for trypsin. Missed cleavages were set up to 2 . As variable modifications, methionine oxidation and $\mathrm{N}$ - and $O$-glycosylation (in-house glycan lists for rhEPO were used) were included. The sequence of human EPO (P01588) without the signal peptide was used as protein database. GlycopeptideGraphMS was used for the assignment of glycopeptides in the MS1 data. Of note, the default glycan building block list used for the GlycopeptideGraphMS search was extended by additional searching blocks in order to connect high mannose, hybrid and complex type glycans. In addition, acetylation, Neu5Gc, phosphorylation and sulfation were added to the compositional output in GlycopeptideGraphMS. The accepted mass difference for glycoform annotation was set to 0.02 Da per included building block (hexose (H): 162.0528, $N$-acetylhexosamine (N): 203.0794, hexose and $N$-acetylhexosamine (HN): 365.1322, fucose (F): 146.0579, $N$-acetylneuraminic acid (S): 291.0954, $N$-glycolylneuraminic acid (G): 307.0903, phosphate (P): 79.9663, sulfate (Su): 79.9568, acetyl (Ac): 42.0106). Connection of high mannose glycans was enabled to hybrid glycans $(+\mathrm{H}+\mathrm{N}+\mathrm{F}, 511.1901)$ and to complex glycans $(-\mathrm{H}-\mathrm{P}+\mathrm{N} 2+\mathrm{S}, 455.2350)$. In addition, complex glycans were connected to hybrid glycans $(+\mathrm{P}+\mathrm{H} 2-\mathrm{N}, 200.9926)$. The maximum retention time restrictions were partly adjusted per peptide portion and ranged as follows $\mathrm{H}: 20$ 30 s, N: 20 s, HN: 40-60 s, F: 5 s, S: 60-150 s, G: 60-150 s, P: 50-60 s, Su: 50-60 s, Ac: 60-100 s, $+\mathrm{H}+\mathrm{N}+\mathrm{F}: 25 \mathrm{~s},-\mathrm{H}-\mathrm{P}+\mathrm{N} 2+\mathrm{S}: 20 \mathrm{~s},+\mathrm{P}+\mathrm{H} 2-\mathrm{N}: 60 \mathrm{~s}$ ). Glycopeptide clusters were generated based on the connectivity between nodes (deconvoluted masses) with the above restrictions and resulted in at least one cluster per peptide portion. Separate retention time clusters were generated based on the number of sialic acids and acetyl groups in the glycan composition. So called reference nodes in the GlycopeptideGraphMS output lists (one node per peptide portion, with a known glycopeptide composition; Figure S2) were confirmed by MS2 data. All compositions in the initial glycoform list were annotated based on the reference nodes. Non-logical compositions, i.e. glycoform compositions with negative features in the final output, were removed. All glycoforms found on all $N$-glycosylation sites in the two different digests (trypsin and GluC) were merged and combined with all identified glycopeptide peptide moieties. The resulting analyte lists was used for targeted data extraction and quality control using LacyTools. The analyte lists were further curated based on quality criteria (IPQ $<0.2$, mass accuracy $<15 \mathrm{ppm}, \mathrm{S} / \mathrm{N}>9$ ) per charge state. In addition, glycoform compositions which passed the quality criteria, but were not described previously and could not be matched to known biosynthetic pathways for protein $N$ glycosylation, were excluded. After a first relative quantification in LacyTools, a reduced analyte list with the most abundant glycoforms ( $>0.5 \%$ relative abundance, excluding acetylation) was additionally quantified in Skyline using manual quality control (idotp $>0.9$, ppm $<5 \mathrm{ppm}$ ) and peak integration. Manual quality control and peak integration was needed for an accurate quantification of all charge states, preventing the interference of signals with similar $m / z$ and RT. 


\section{S-2 Supporting Information - Figures}

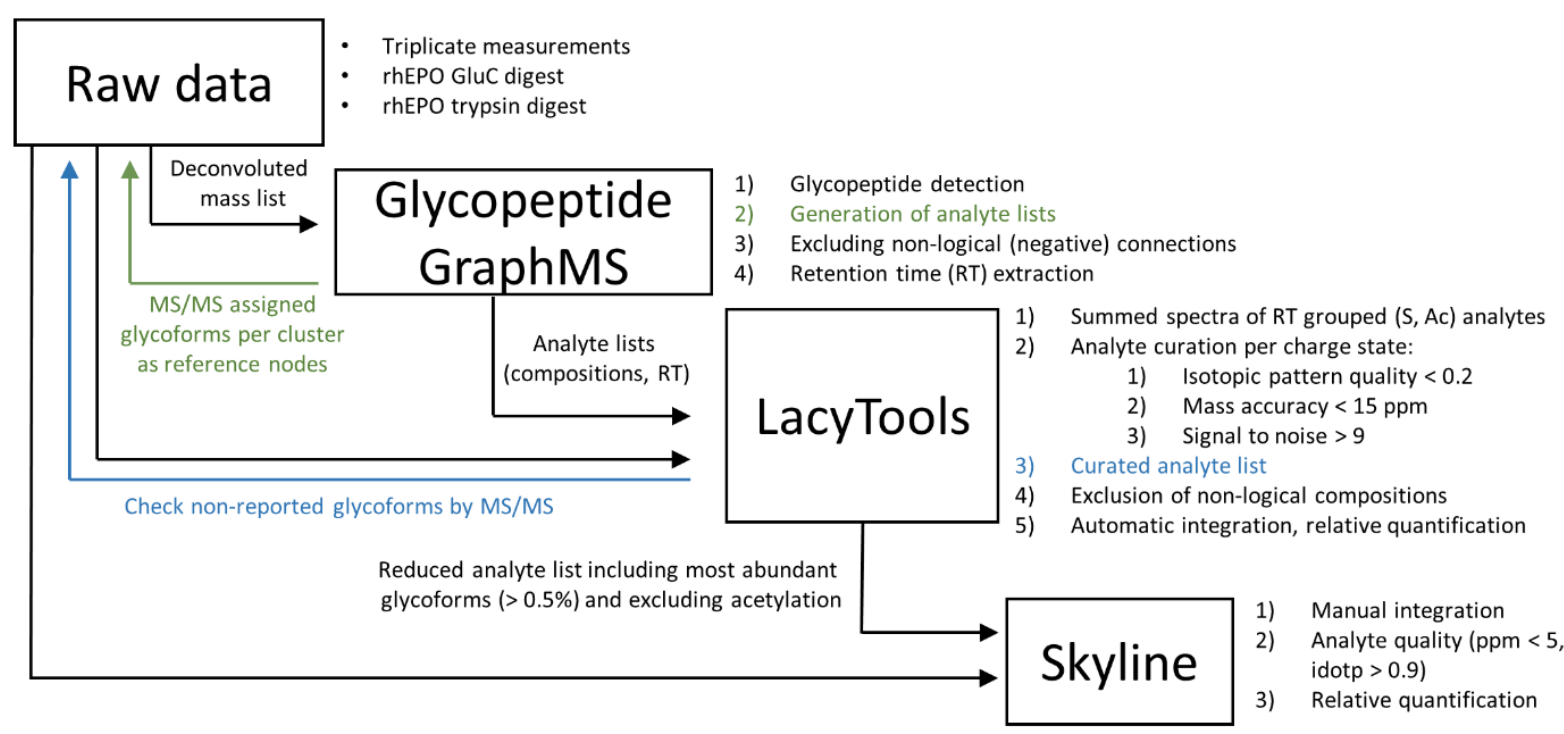

Figure S1: Visualization of the glycopeptide data evaluation workflow. 

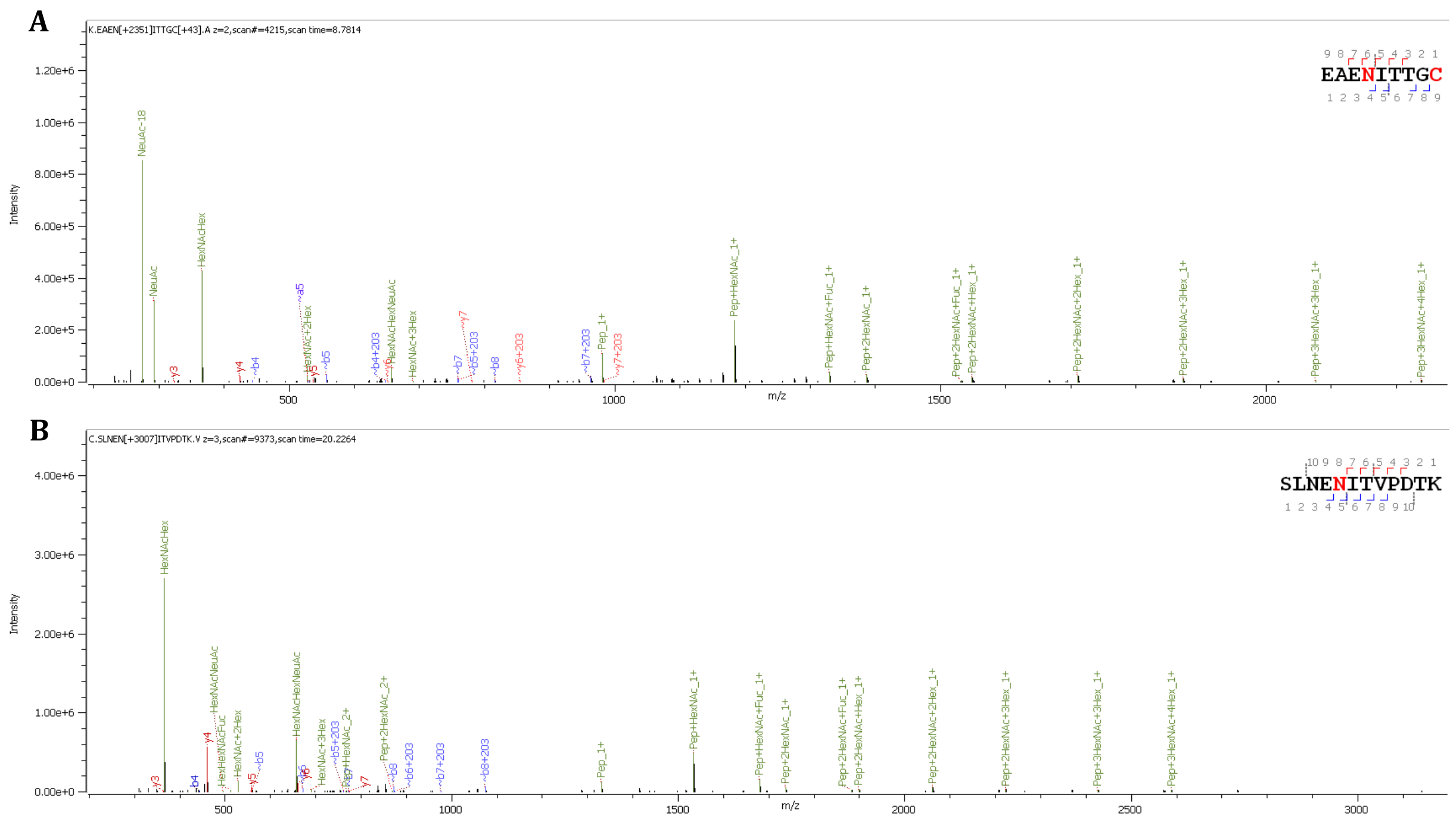

Figure S2: Glycopeptide assignments by MS2 of a tryptic rhEPO digest with HCD fragmentation. One glycoform per glycopeptide cluster is represented (A) Asn24-H5N4F1S2, (B) Asn38-H6N5F1S3, (C) Asn83-H6N5F1S3 and (D) Ser126-H1N1S2. 

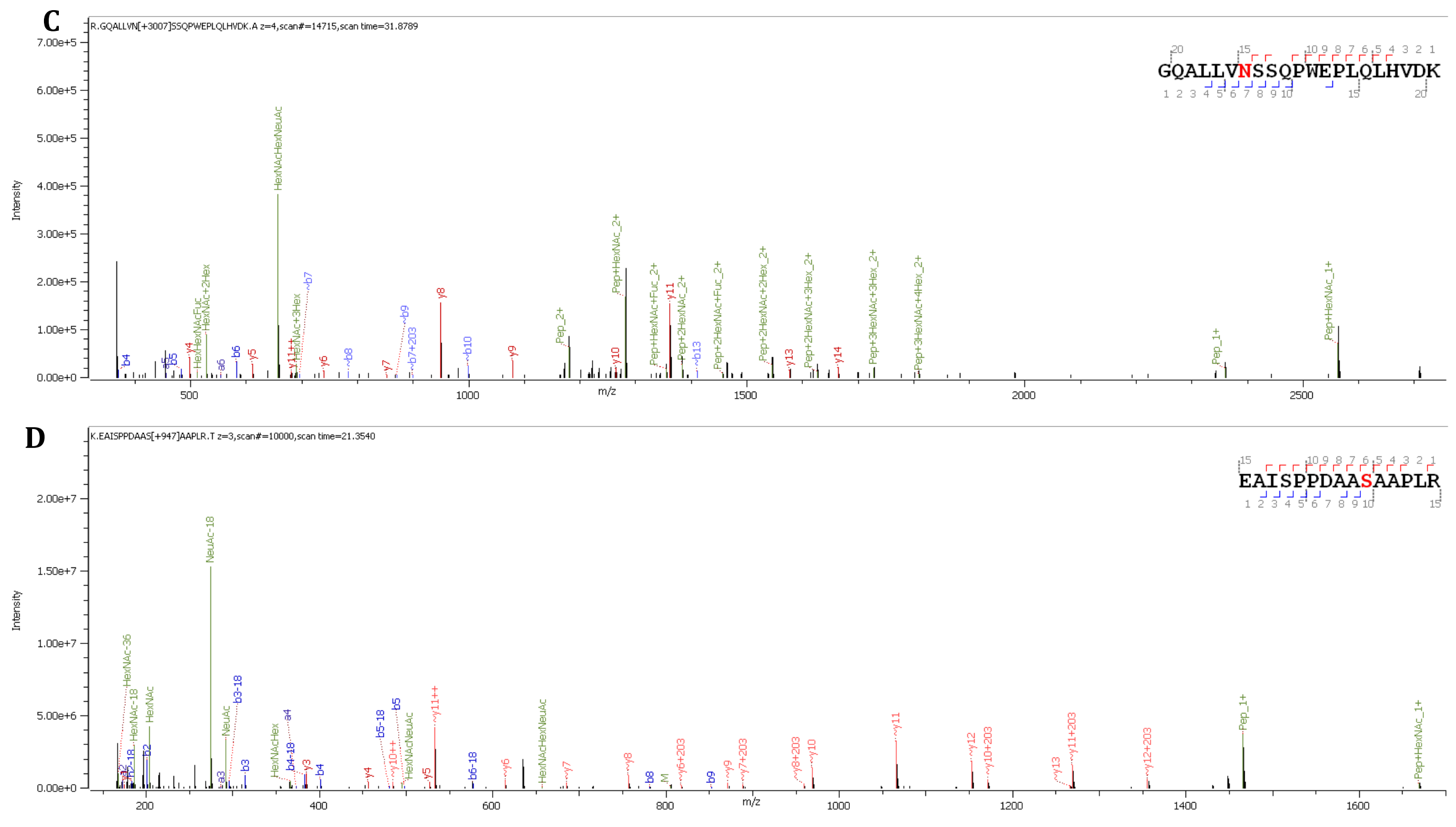

Continuation Figure S2: Glycopeptide assignments by MS2 of a tryptic rhEPO digest with HCD fragmentation. One glycoform per glycopeptide cluster is represented (A) Asn24-H5N4F1S2, (B) Asn38-H6N5F1S3, (C) Asn83-H6N5F1S3 and (D) Ser126-H1N1S2. 


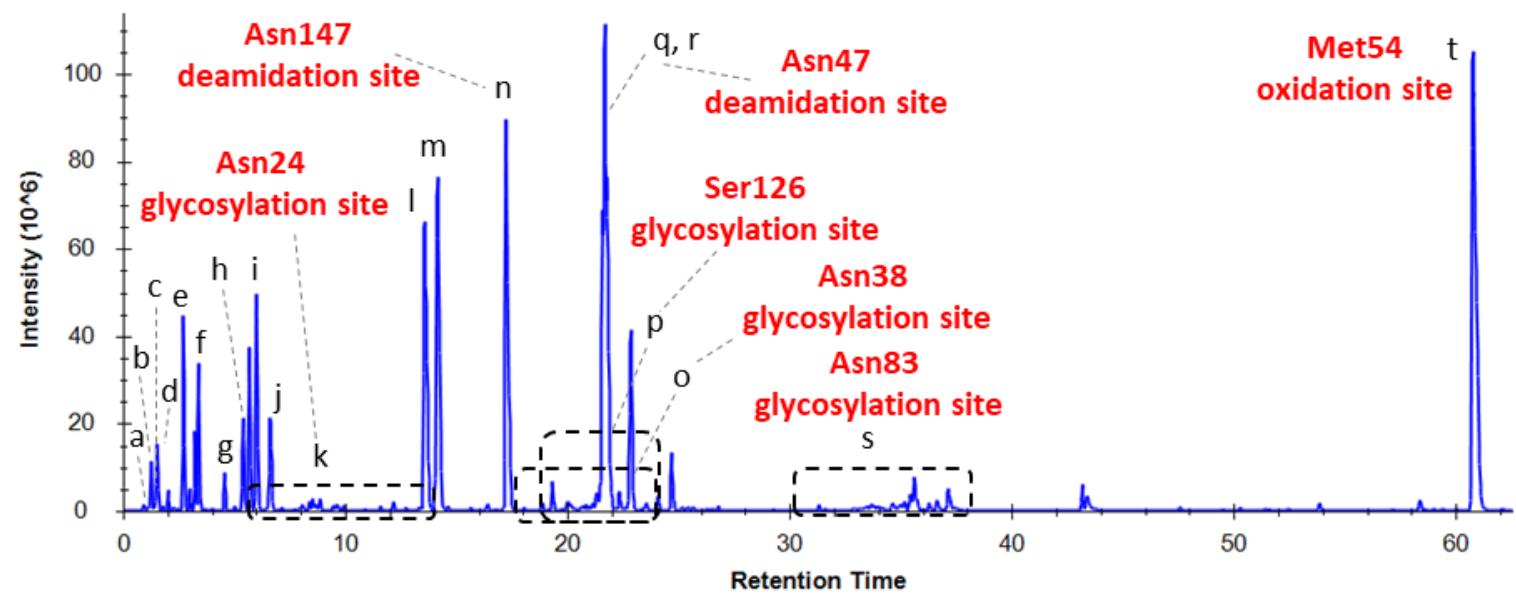

Figure S3: Base peak chromatogram of a representative tryptic EPO digest upon cysteine aminoethylation. The peak assignment is listed in Table S2. 

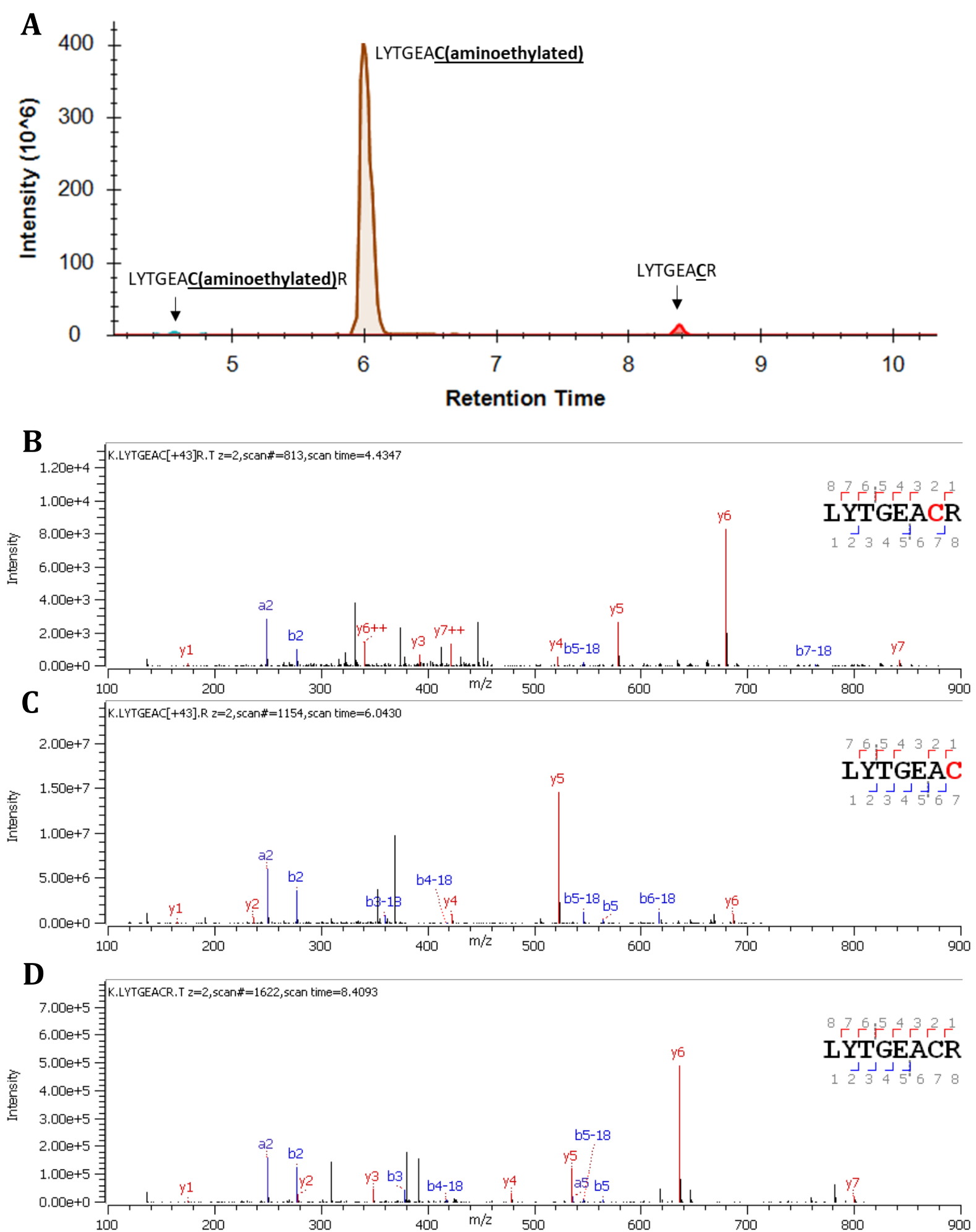

Figure S4: MS1 and MS2 data for cysteine 160 containing peptides used for the assessment of 2-bromoethylamine alkylation and tryptic digestion efficiencies. (A) Extracted ion chromatrograms of peptides of interest: LYTGEAC(aminoethylated)R, LYTGEAC(aminoethylated) and LYTGEACR. MS2 assignments are shown for (B) alkylated and cleaved LYTGEAC(aminoethylated), (C) alkylated and uncleaved LYTGEAC(aminoethylated)R and for (D) unalkylated LYTGEACR. 

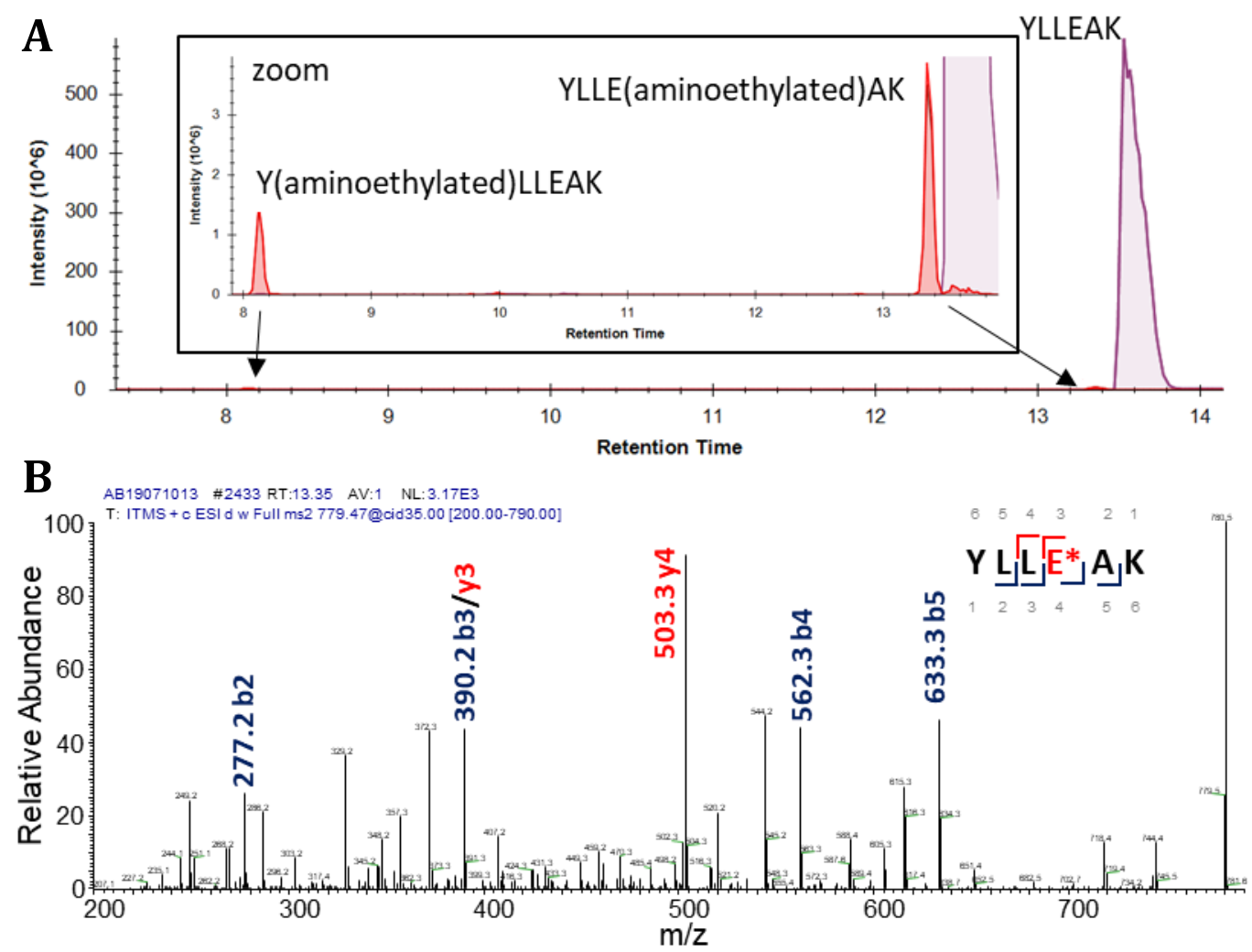

Figure S5: 2-bromoethylamine alkylation selectivity for YLLEAK peptide. (A) EIC of MS1 signals and (B) representative MS2 spectrum for alkylated Glu. MS2 data for Tyr alkylation are not shown. 

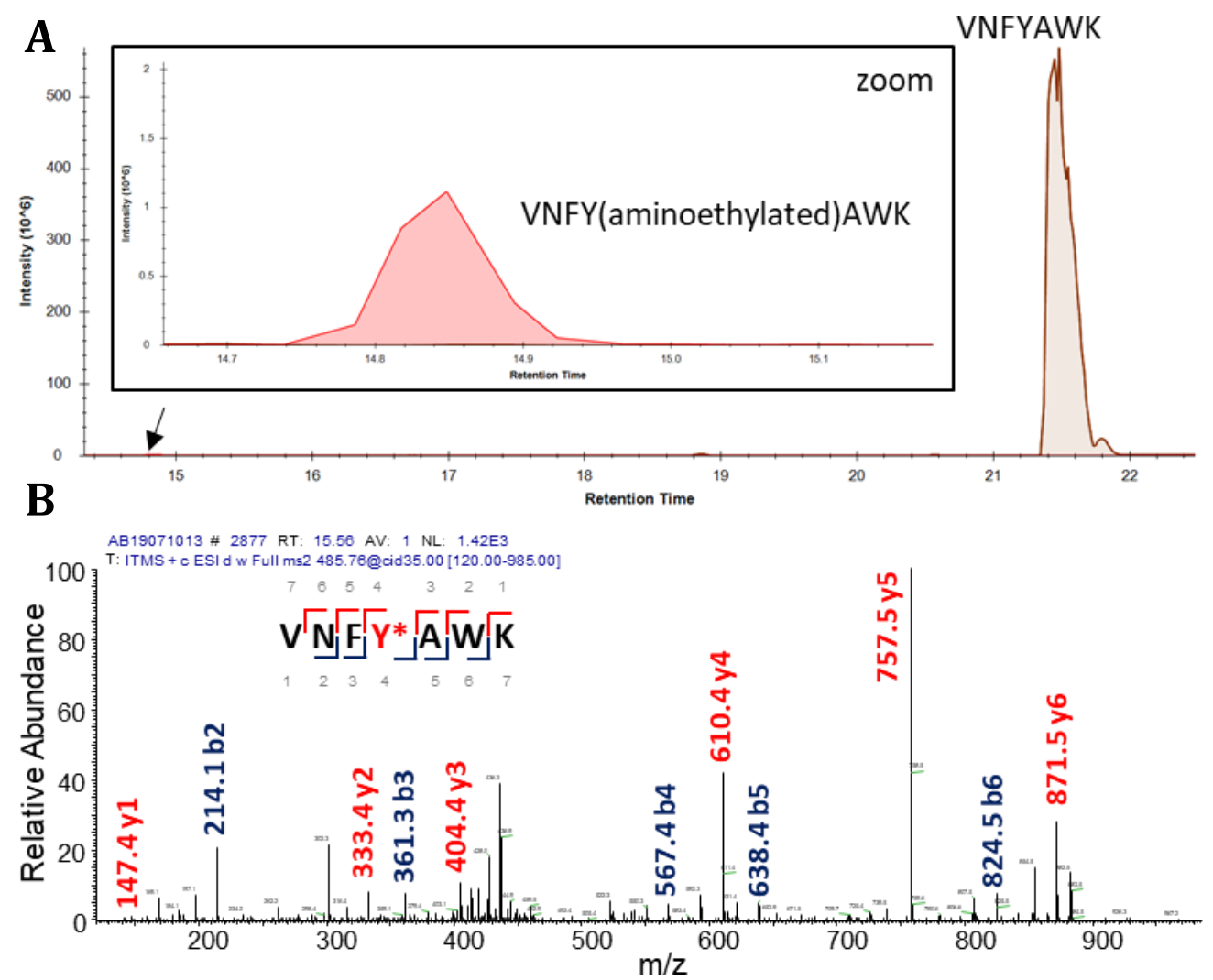

Figure S6: 2-bromoethylamine alkylation selectivity for VNFYAWK peptide. (A) EIC of MS1 signals and (B) representative MS2 spectrum for alkylated Tyr. 

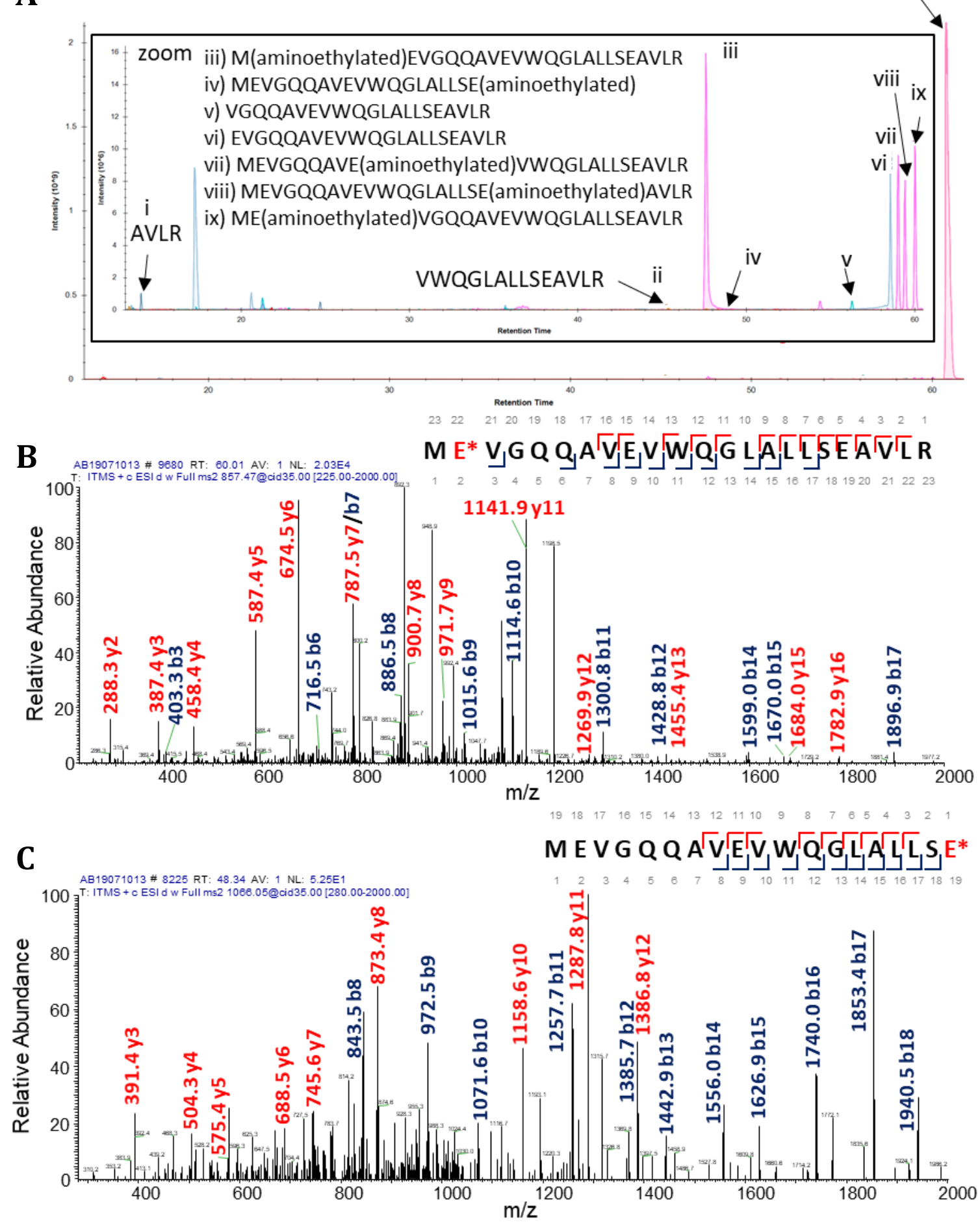

Figure S7: 2-bromoethylamine alkylation selectivity for MEVGQQAVEVWQGLALLSEAVLR peptide. (A) EIC of MS1 signals for unselectively alkylated and for unexpected tryptic cleavage products, (B) representative MS2 spectrum for an unselectively alkylated peptide* and (C) representative MS2 spectrum of an aminoethylated glutamic acid cleaved by trypsin.

*The position of Glu alkylation was confirmed by MS2 assignments for vii and viii (data not shown). It was assumed that peak iii was alkylated on Met and ix on Glu (B) based on the elution order and intensity difference compared to the other confirmed alkylated Glu (vii and viii). A MS2 assignment of the alkylation position on the first amino acid (Met) or the second amino acid (Glu) was not possible with the applied method. 

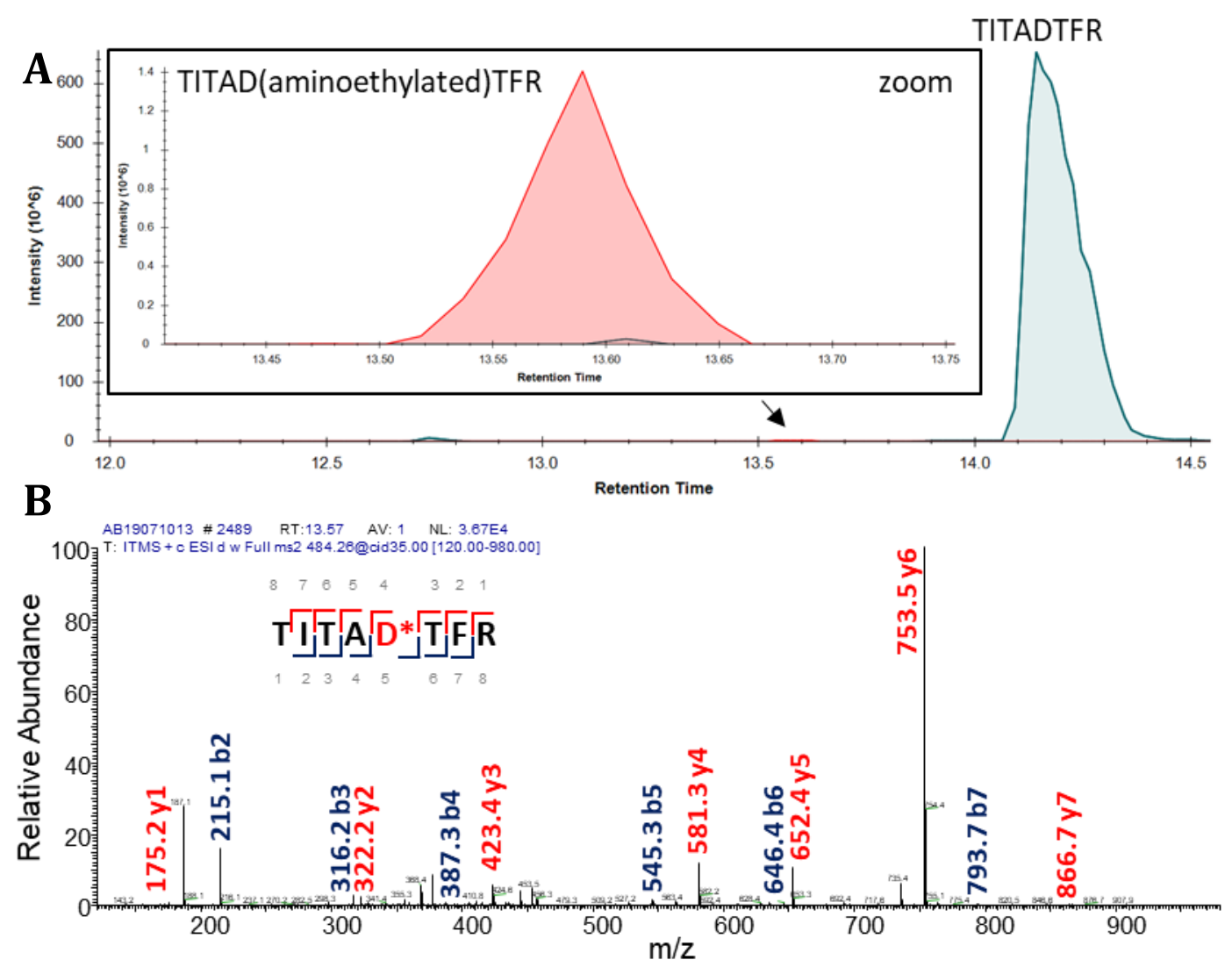

Figure S8: 2-bromoethylamine alkylation selectivity for TITADTFR peptide. (A) EIC of MS1 signals and (B) representative MS2 spectrum for alkylated Asp. 
A

VYSNFLR

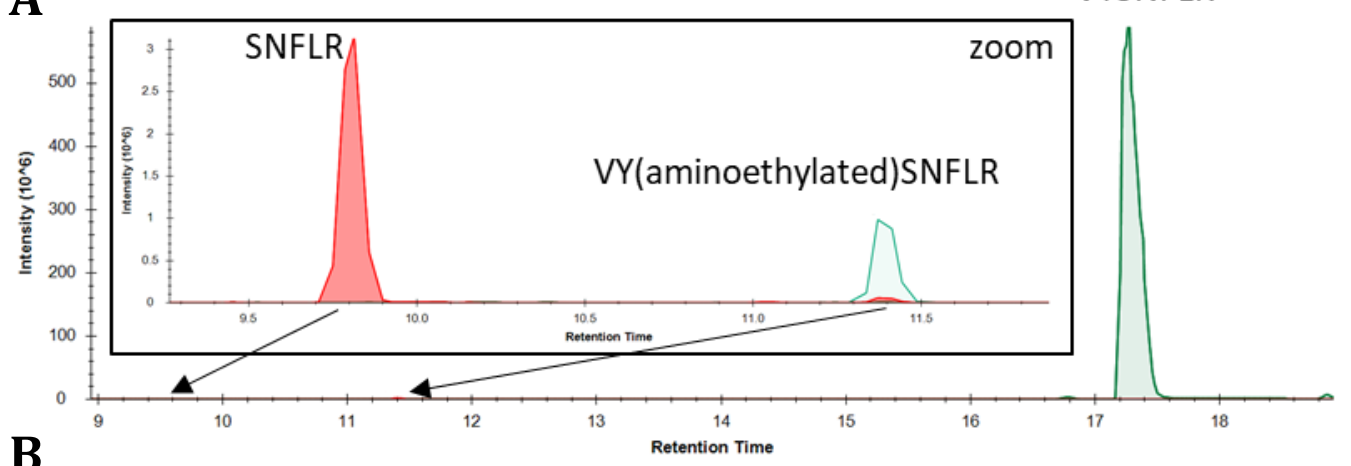

B

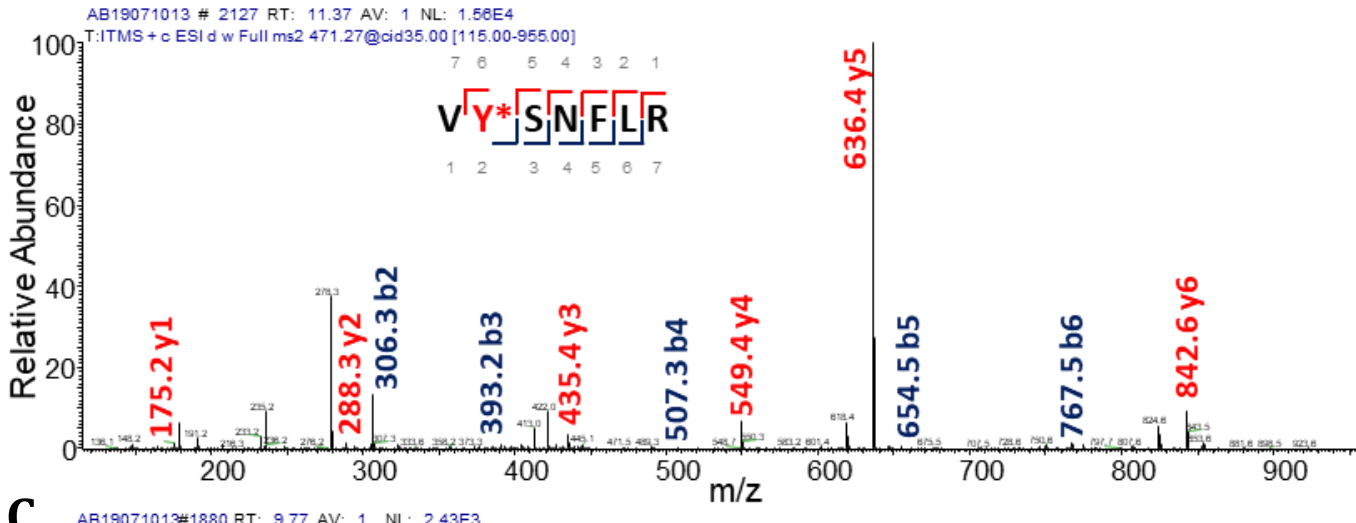

C AB19071013 $1880 \mathrm{RT}: 9.77 \mathrm{AV}: 1$ NL: 2.43E3

$\mathrm{m} / \mathrm{z}$

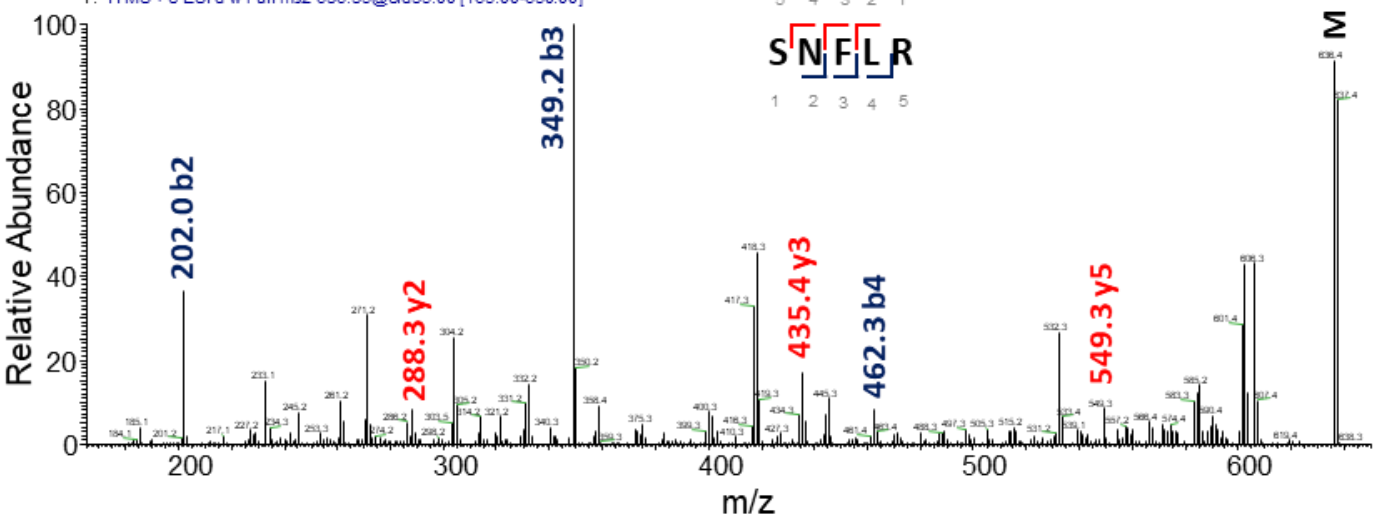

Figure S9: 2-bromoethylamine alkylation selectivity for VYSNFLR peptide. (A) EIC of MS1 signals, (B) representative MS2 spectrum for alkylated Tyr and (C) representative MS2 spectrum for tryptic cleavage product of the $O$-alkylated Tyr. 

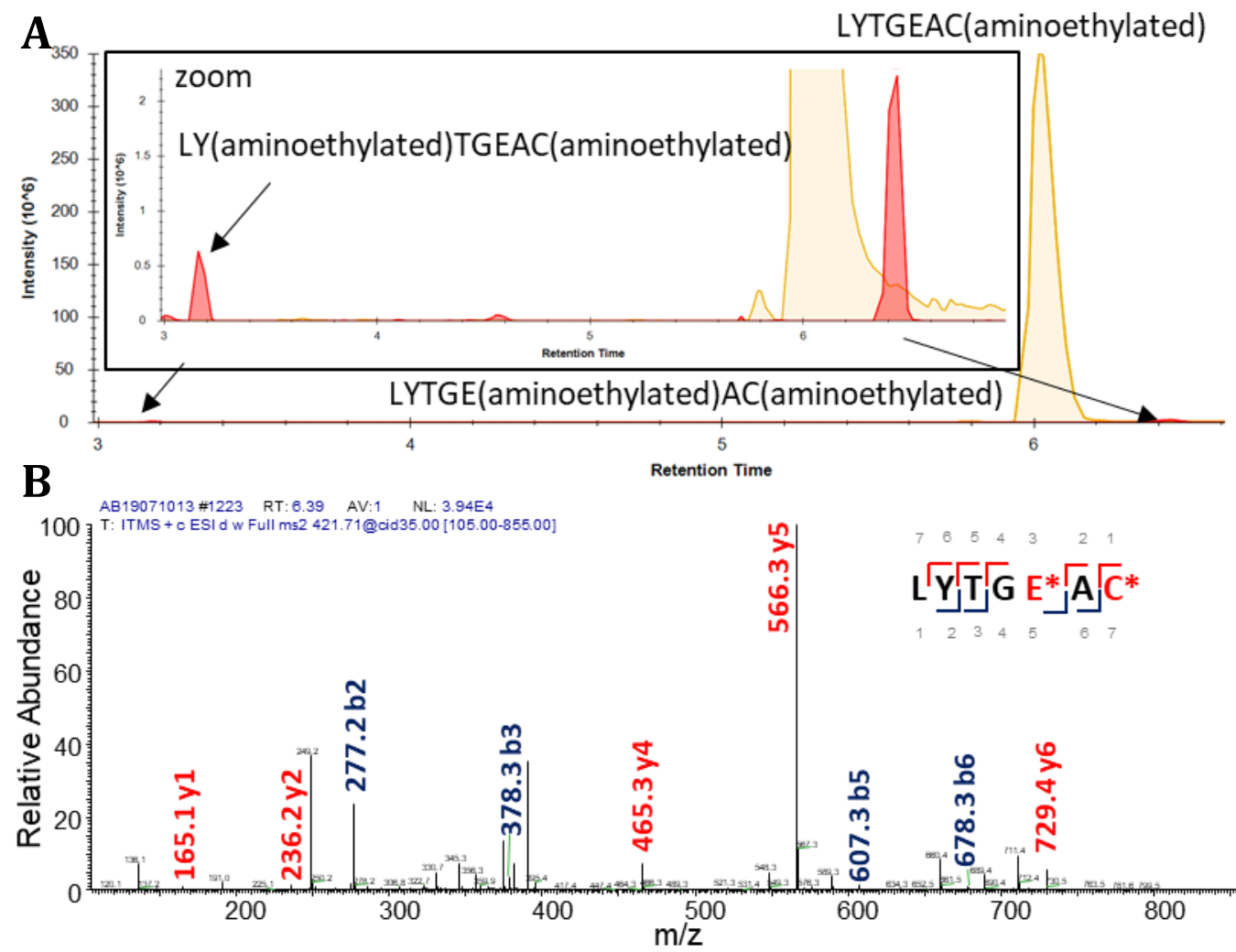

Figure S10: 2-bromoethylamine alkylation selectivity for LYTGEAC* peptide. (A) EIC of MS1 signals and (B) representative MS2 spectrum for alkylated Glu. MS2 data for Tyr alkylation are not shown. 

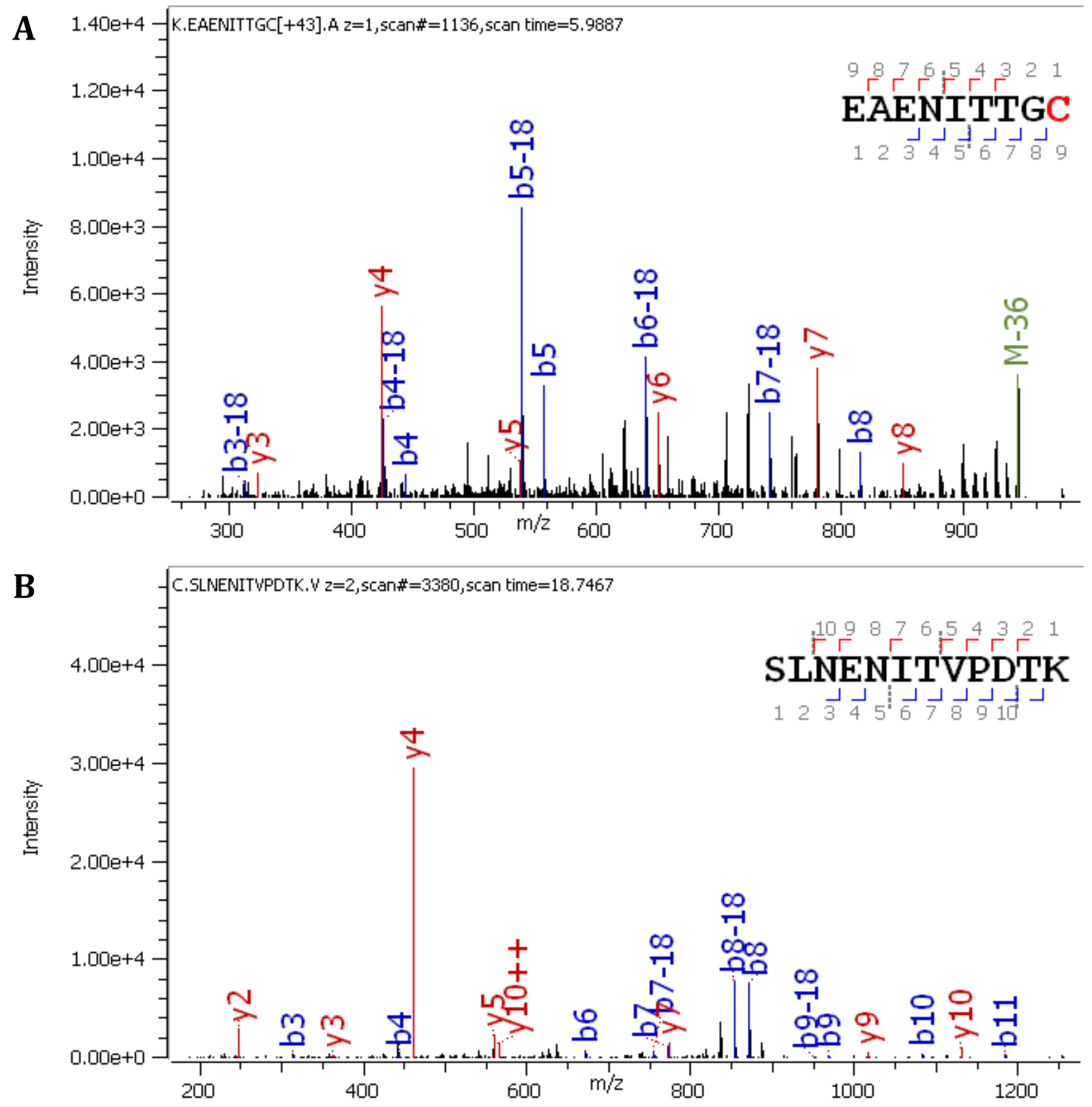

Figure S11: MS2 assignment of non-glycosylated variants of tryptic (A) Asn24 and (B) Asn 38 peptides upon cysteine aminoethylation. 


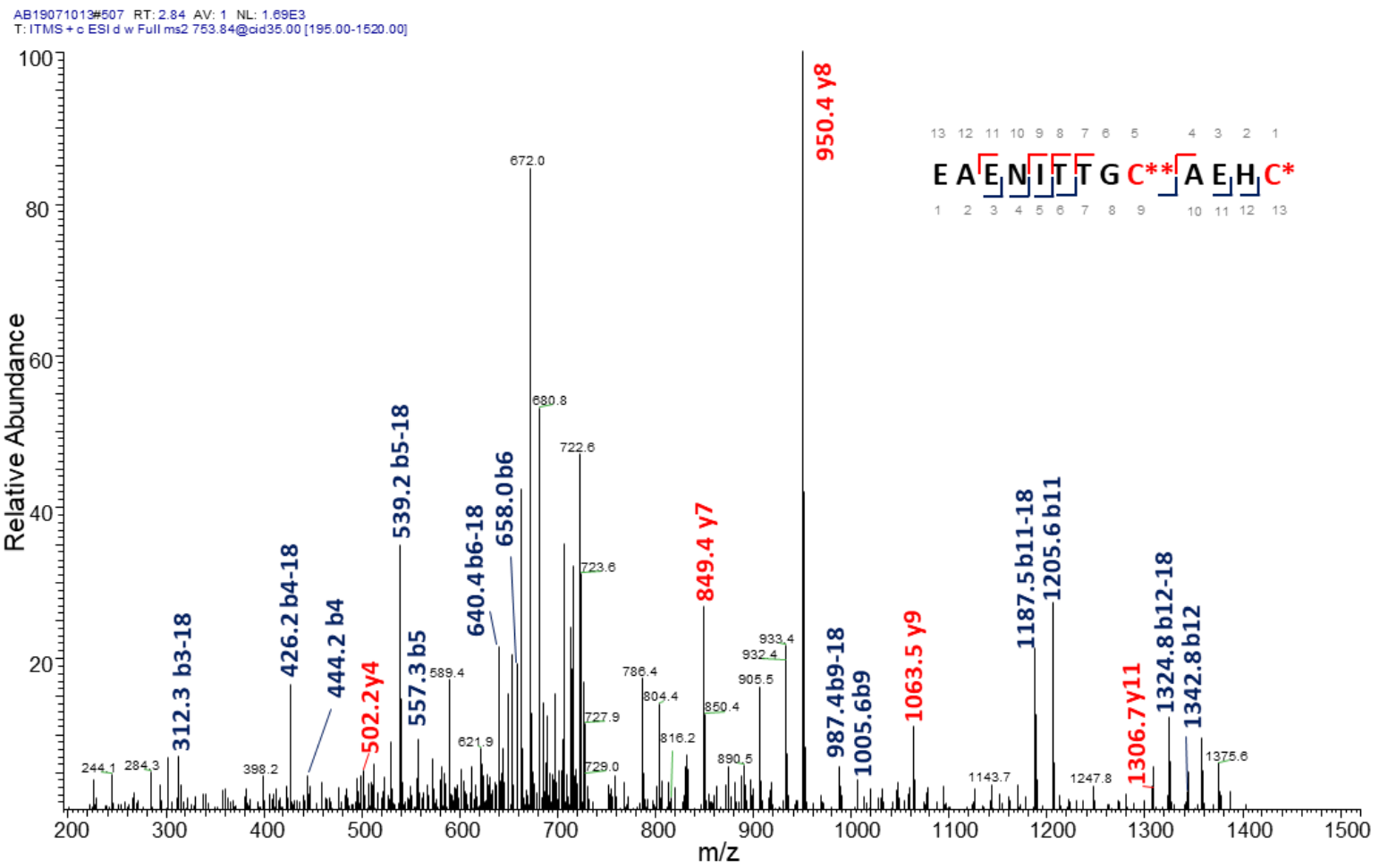

Figure S12: MS2 assignment of the non-glycosylated, missed cleaved and overalkylated Asn24 peptide. 

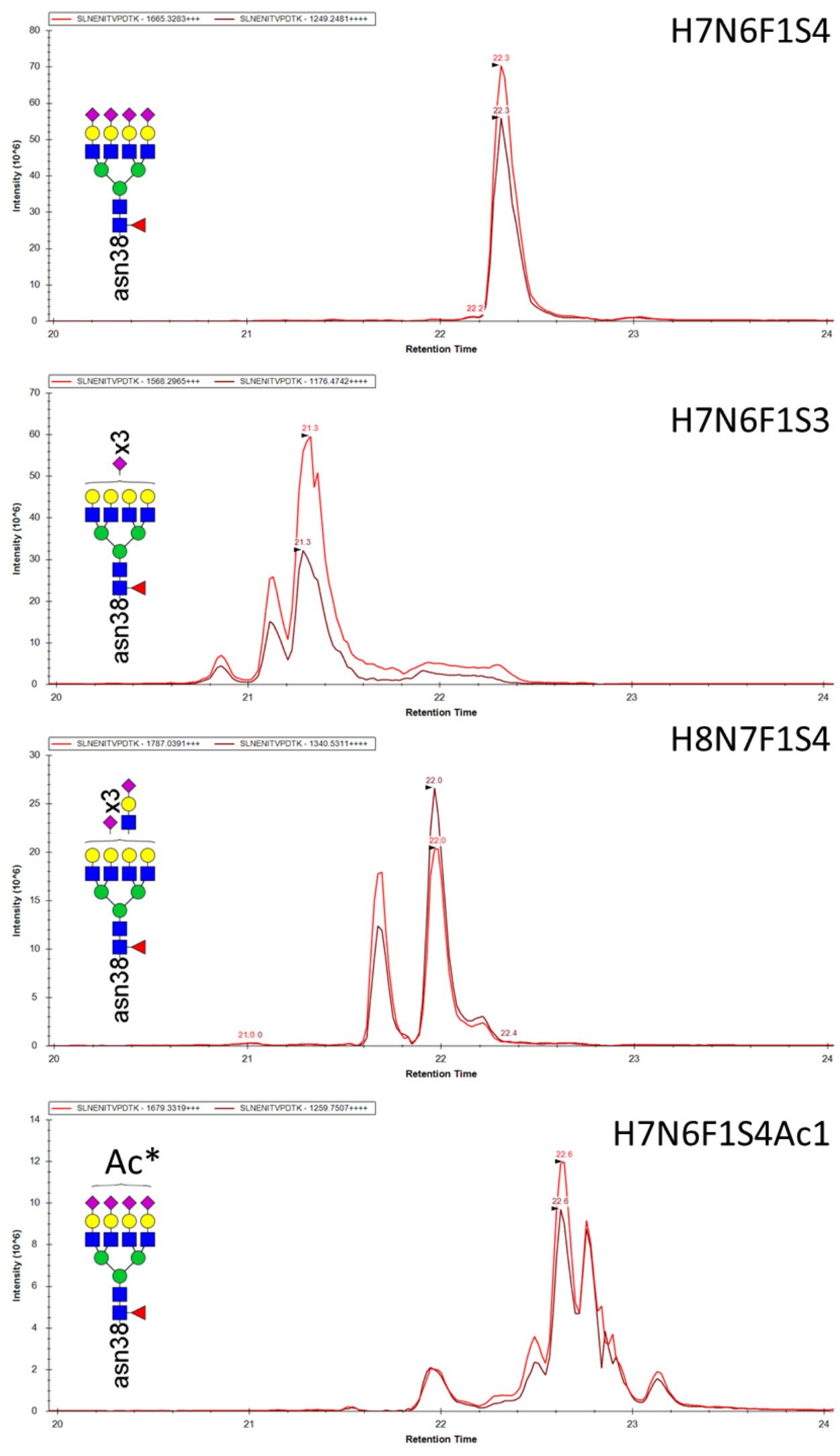

Figure S13: Examples for isomer separation obtained for rhEPO glycopeptides by RP-LCMS/MS. Representative glycoforms of the tryptic Asn38 peptide (SLNENITVPDTK) showing compositional sialic acid and acetylation isomers. Structural assignments of the peaks were not performed. 


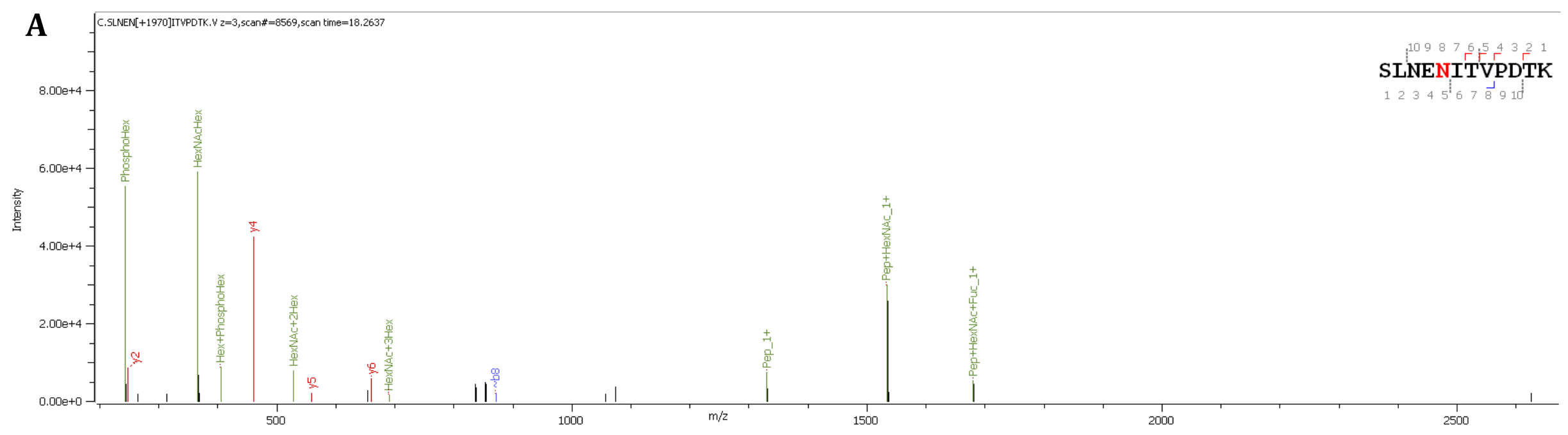

B

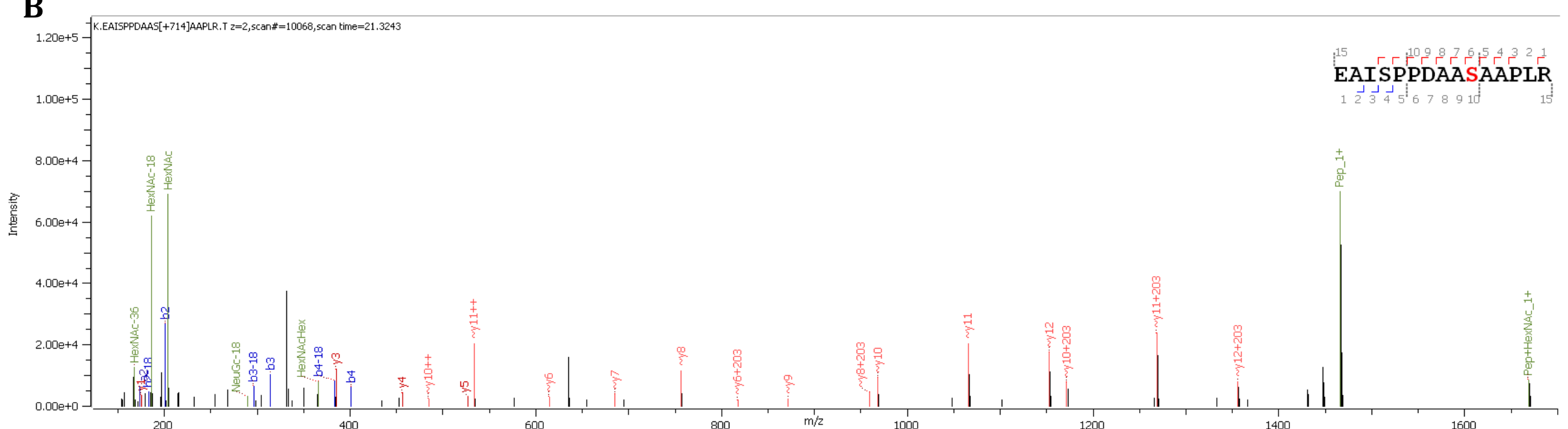

Figure S14: MS2 data of glycoforms which were not reported for rhEPO previously. (A) Asn38-H7N3F1P1, (B) Ser126-H1N1G1Ac1, (C) Ser126H1N1S1G1Ac1 and (D) Ser126-H1N1S3. 

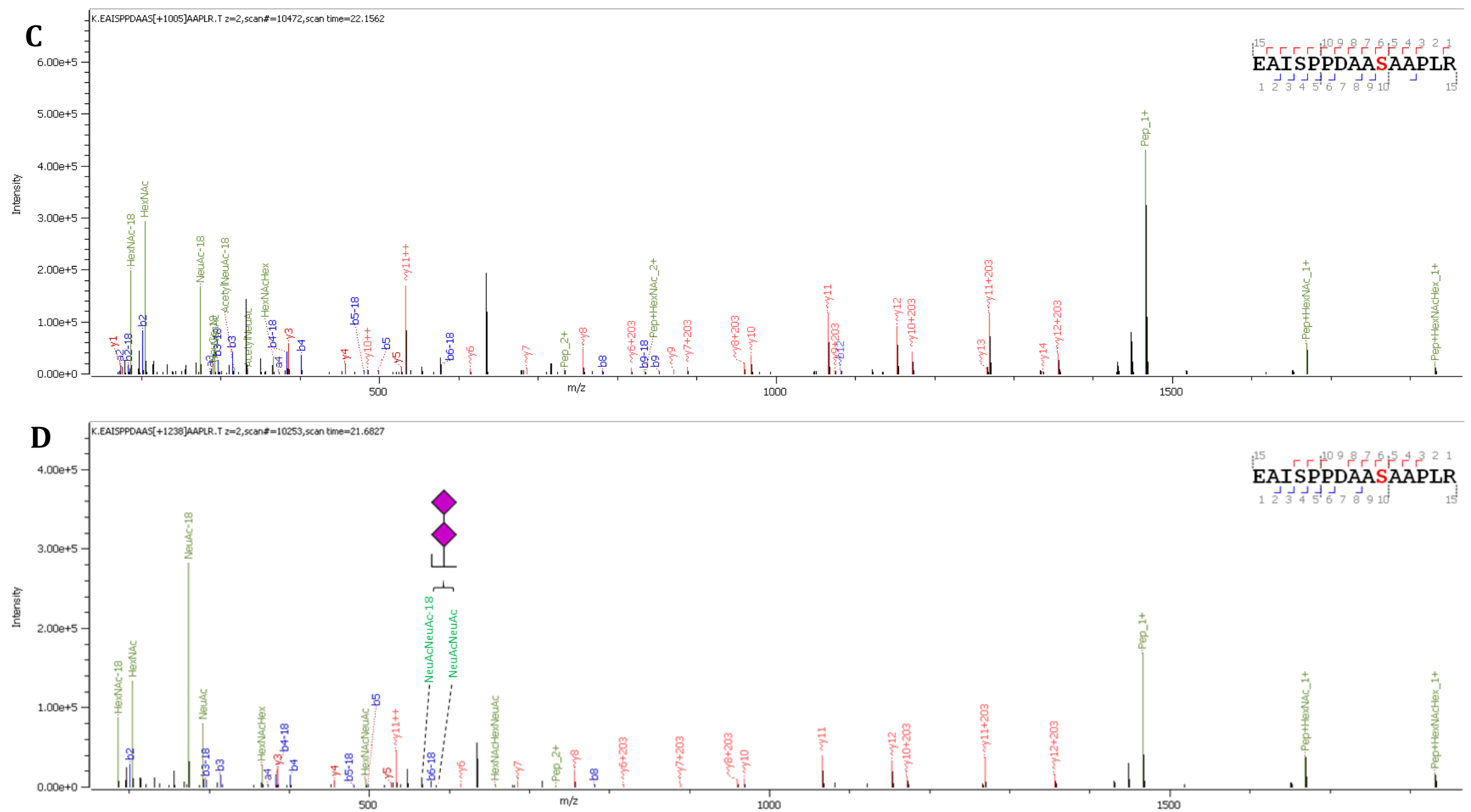

Figure S14: MS2 data of glycoforms which were not reported for rhEPO previously. (A) Asn38-H7N3F1P1, (B) Ser126-H1N1G1Ac1, (C) Ser126H1N1S1G1Ac1 and (D) Ser126-H1N1S3. 


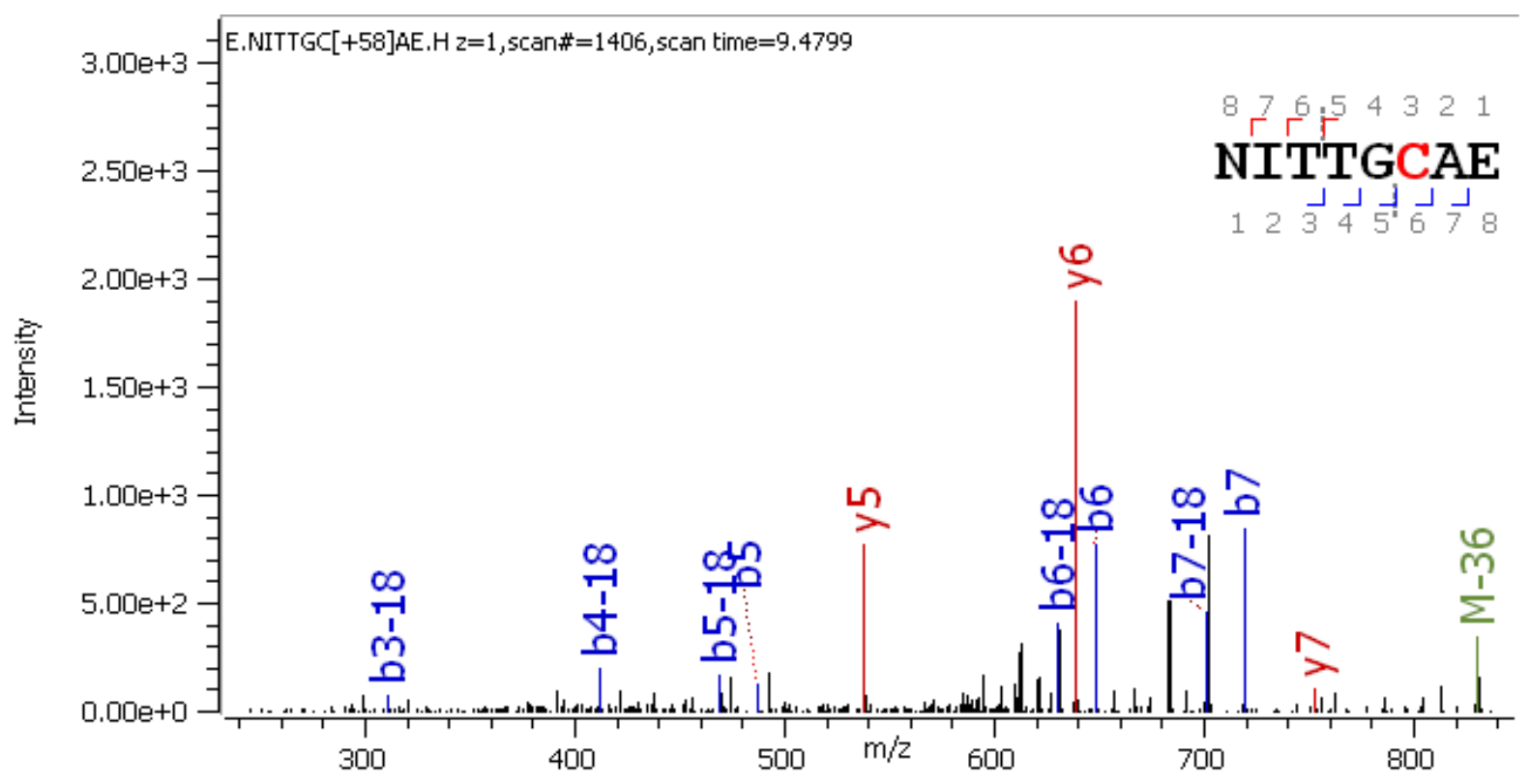

Figure S15: Asn24 GluC non-glycosylated variant with cleavage adjacent to the glycosylation site. Glycopeptides were not observed for this peptide moiety. 

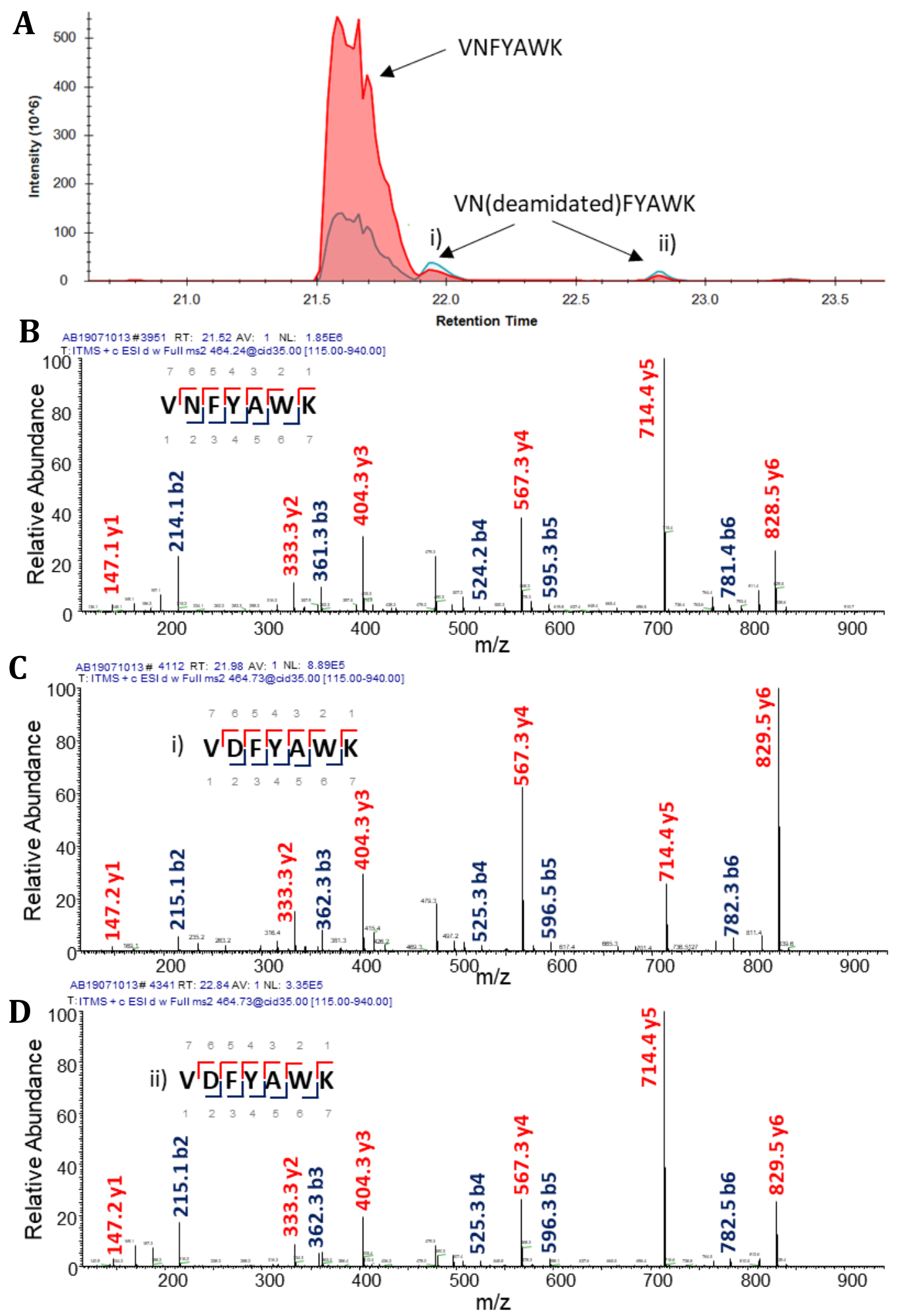

Figure S16: Tryptic rhEPO Asn47 deamidation site. (A) EICs* of MS1 signals. MS2 assignments of (B) unmodified peptide, (C) deamidated peptide i) ${ }^{* *}$ and (D) deamidated peptide ii) ${ }^{* *}$.

* Visually overlapping traces result from partial overlaps in the isotopes of the non-modified and deamidated peptides within the extracted $\mathrm{m} / \mathrm{z}$ window.

${ }^{* *}$ The separation of isomeric deamidation products is likely to result from the presence of aspartic acid and isoaspartic acid. However, the applied method does not allow to reliably distinguish the different isomers. ${ }^{2}$ 

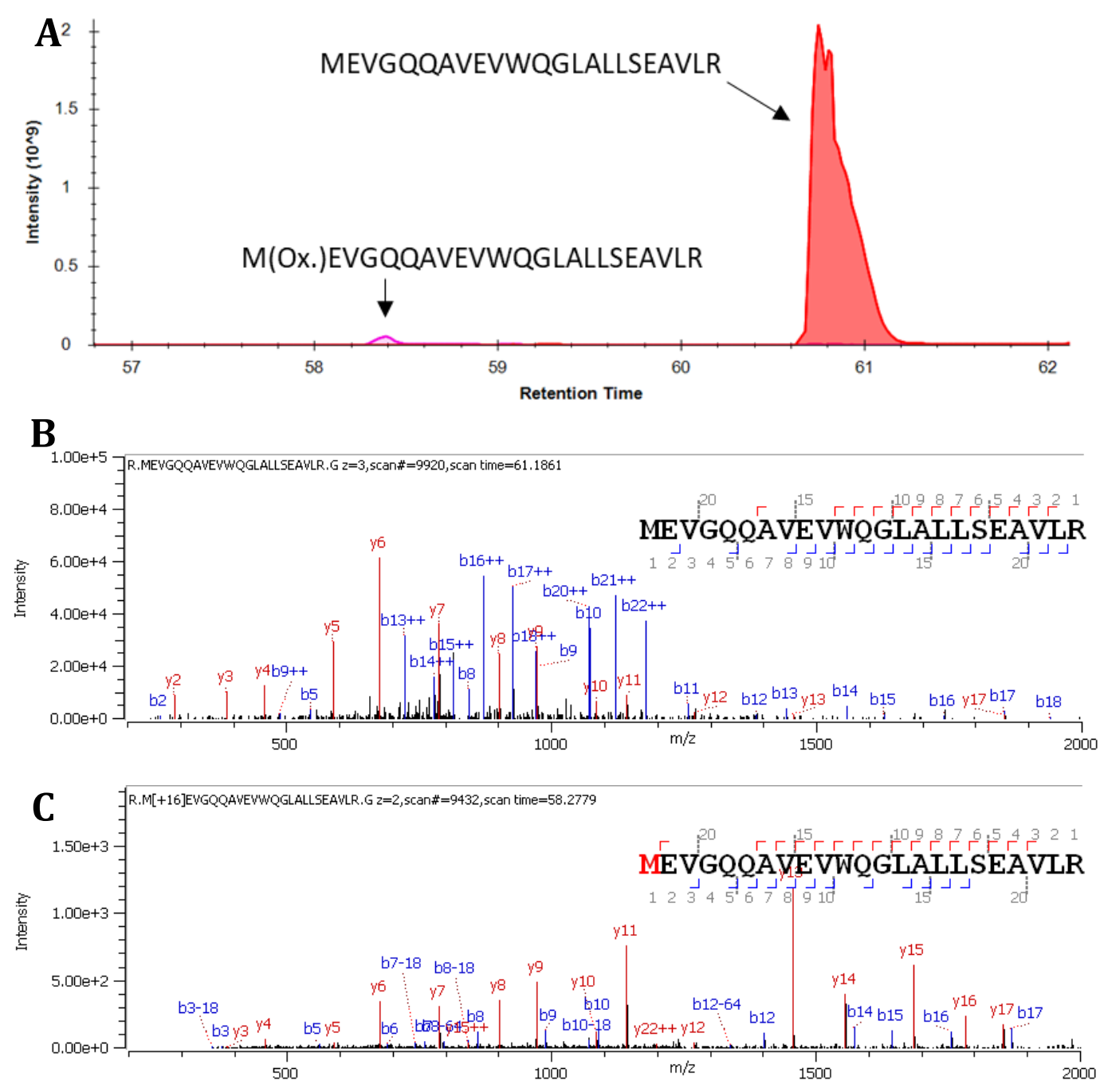

Figure S17: Tryptic rhEPO Met54 oxidation site. (A) EICs of MS1 signals. MS2 assignments of (B) unmodified peptide and (C) oxidized peptide. 

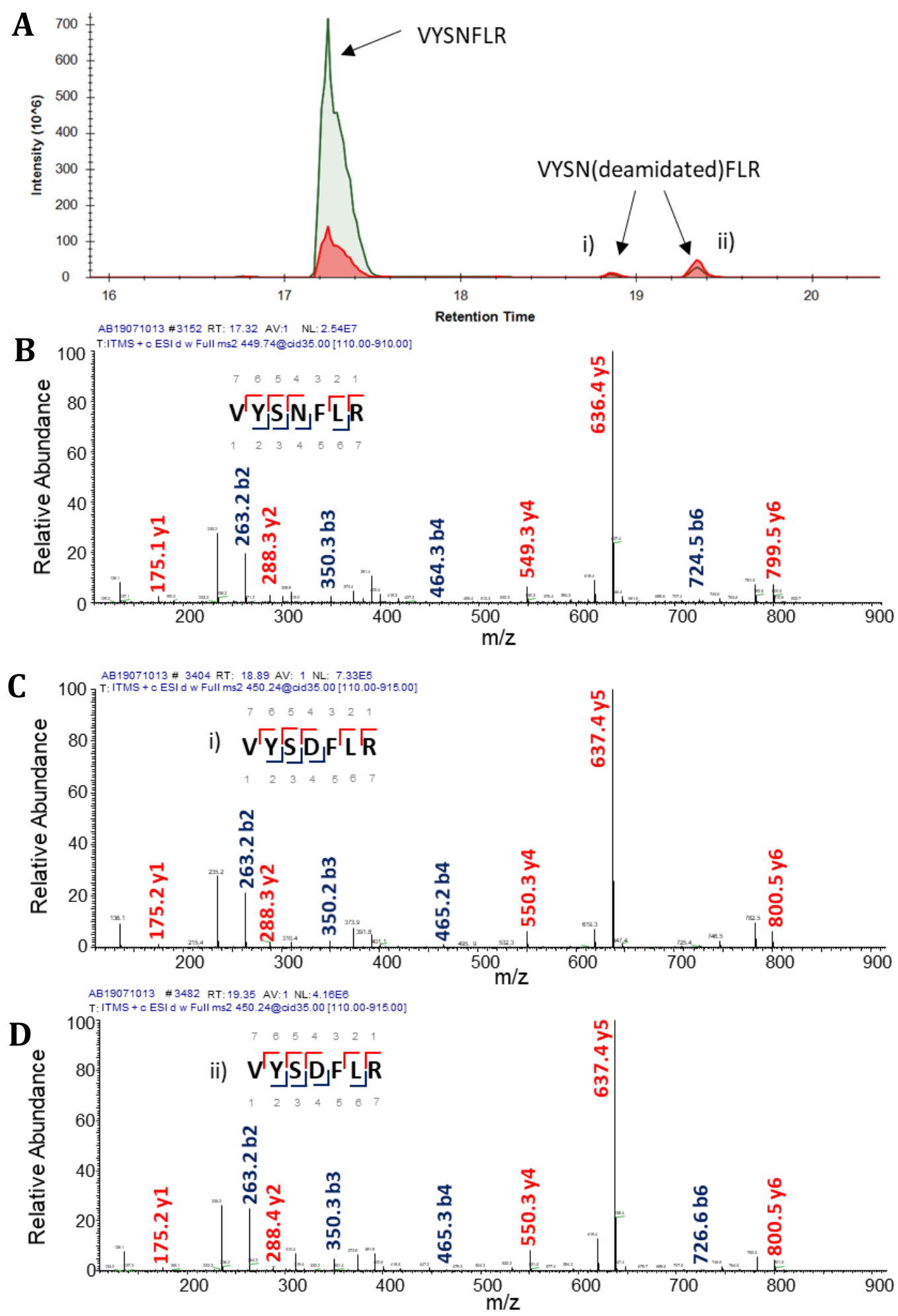

Figure S18: Tryptic rhEPO Asn147 deamidation site. (A) EICs* of MS1 signals. MS2 assignments of (B) unmodified peptide, (C) deamidated peptide i)** and (D) deamidated peptide ii)**.

* Visually overlapping traces result from partial overlaps in the isotopes of the non-modified and deamidated peptides within the extracted $\mathrm{m} / \mathrm{z}$ window.

**The separation of isomeric deamidation products is likely to result from the presence of aspartic acid and isoaspartic acid. However, the applied method does not allow to reliably distinguish the different isomers. ${ }^{2}$ 


\section{S-3 Supporting Information - Tables}

Table S1: RP-LC gradient.

\begin{tabular}{|l|l|}
\hline Time [min] & \%B \\
\hline 0 & 1 \\
\hline 30 & 20 \\
\hline 60 & 35 \\
\hline 65 & 80 \\
\hline 75 & 99 \\
\hline 75.1 & 1 \\
\hline 80 & 1 \\
\hline
\end{tabular}

Table S2: Expected tryptic EPO peptides upon cysteine aminoethylation containing at least 3 amino acids.

\begin{tabular}{|c|c|c|c|}
\hline Position & Sequence & Label (see Figure S3) & RT (min) \\
\hline $1-4$ & APPR & $\mathrm{d}$ & 1.5 \\
\hline 5-7 & LIC* $^{*}$ & $\mathrm{~g}$ & 4.5 \\
\hline $8-10$ & DSR & $\mathrm{b}$ & 1.2 \\
\hline $11-14$ & VLER & $\mathrm{f}$ & 3.4 \\
\hline $15-20$ & YLLEAK & l & 13.5 \\
\hline $21-29$ & EAENITTGC* & $\mathrm{k}$ & $6-14$ \\
\hline $30-33$ & AEHC* & $\mathrm{a}$ & 0.9 \\
\hline $34-45$ & SLNENITVPDTK & o & $18-24$ \\
\hline $46-52$ & VNFYAWK & $q$ & 21.6 \\
\hline $54-76$ & MEVGQQAVEVWQGLALLSEAVLR & $\mathrm{t}$ & 60.8 \\
\hline $77-97$ & GQALLVNSSQPWEPLQLHVDK & s & $30-38$ \\
\hline $98-103$ & AVSGLR & $\mathrm{h}$ & 5.7 \\
\hline $104-110$ & SLTTLLR & $\mathrm{r}$ & 21.7 \\
\hline $111-116$ & ALGAQK & $\mathrm{e}$ & 2.7 \\
\hline $117-131$ & EAISPPDAASAAPLR & $\mathrm{p}$ & $19-24$ \\
\hline $132-139$ & TITADTFR & $\mathrm{m}$ & 14.1 \\
\hline $141-143$ & LFR & $\mathrm{j}$ & 6.6 \\
\hline $144-150$ & VYSNFLR & $\mathrm{n}$ & 17.3 \\
\hline $155-161$ & LYTGEAC* & i & 6.0 \\
\hline $163-165$ & TGD & $\mathrm{c}$ & 1.3 \\
\hline
\end{tabular}

* Aminoethylation (+ 43.0422 Da)

Table S3: Assessment of alkylation and tryptic digestion efficiency of aminoethylated cysteine by 2-bromoethylamine.

\begin{tabular}{|l|l|l|}
\hline Efficiency & Mean (\%) & STD (\%) \\
\hline Alkylation* & 97.3 & 0.5 \\
\hline Tryptic digestion** & 99.3 & 0.1 \\
\hline
\end{tabular}

* The alkylation efficiency was assessed by the fraction of the sum of alkylated peptides (LYTGEAC(aminoethylated) + LYTGEAC(aminoethylated)R) compared to the overall peak areas of the two alkylated peptides and the unalkylated peptide (LYTGEACR).

** The tryptic digestion efficiency was calculated by dividing the peak area of the alkylated and cleaved peptide (LYTGEAC(aminoethylated)) by the overall peak areas of the cleaved/uncleaved peptide (LYTGEAC(aminoethylated)/R). 
Table S4: Assessment of alkylation specificity of 2-bromoethylamine.

\begin{tabular}{|c|c|c|c|c|}
\hline Peptide & $\begin{array}{l}+43.0422 \mathrm{Da} \\
\text { mass } \\
\text { increase? }\end{array}$ & $\begin{array}{l}\text { MS2 } \\
\text { assignment }\end{array}$ & $\begin{array}{l}\text { Alkylation } \\
\text { efficiency**: } \\
\text { Amino acid } \\
(\text { Mean } \pm \text { STD \%) }\end{array}$ & $\begin{array}{l}\text { Additional } \\
\text { tryptic } \\
\text { cleavage } \\
\text { product? }\end{array}$ \\
\hline YLLEAK & + & Figure S5 & $\begin{array}{l}Y(0.1 \pm 0.02) . \mathrm{E}(0.4 \\
\pm 0.02)\end{array}$ & - \\
\hline VNFYAWK & + & Figure S6 & $\mathrm{Y}(0.1 \pm 0.01)$ & - \\
\hline MEVGQQAVEVWQGLALLSEAVLR & + & Figure S7 & $\begin{array}{l}\mathrm{M}(0.6 \pm 0.02) \\
\mathrm{E}(0.6 \pm 0.01)\end{array}$ & + \\
\hline SLTTLLR & - & - & - & - \\
\hline TITADTFR & + & Figure S8 & $\mathrm{D}(0.1 \pm 0.01)$ & - \\
\hline VYSNFLR & + & Figure S9 & $\mathrm{Y}(0.1 \pm 0.02)$ & + \\
\hline LYTGEAC* & + & Figure S10 & $\begin{array}{l}\mathrm{Y}(0.1 \pm 0.03) \\
\mathrm{E}(0.4 \pm 0.2)\end{array}$ & - \\
\hline
\end{tabular}

* aminoethylated, +43.0422

** Alkylation efficiencies were calculated as fractions of the alkylated product of the overall intensities from the alkylated and unalkylated peptides.

Table S5: Overview of assigned peptide moieties for GluC derived and tryptic rhEPO glycopeptides.

\begin{tabular}{|c|c|c|c|c|c|}
\hline Protease & $\begin{array}{l}\text { Glycosylation } \\
\text { site }\end{array}$ & Position & Sequence & Mass (Da) & Hydrophobicity $\dagger$ \\
\hline \multirow{11}{*}{ GluC } & \multirow{2}{*}{ Asn24 } & $22-31$ & AENITTGC+AE & 1065.4285 & 5.94 \\
\hline & & $19-31$ & AKEAENITTGC+AE & 1393.6031 & 7.64 \\
\hline & \multirow{4}{*}{ Asn38 } & $32-55$ & $\begin{array}{l}\text { HC+SLNENITVPDTKVNFYAWKR } \\
\text { ME }\end{array}$ & 2952.3898 & 34.38 \\
\hline & & $38-55$ & NITVPDTKVNFYAWKRME & 2211.1147 & 36.86 \\
\hline & & $32-43$ & HC+SLNENITVPD & 1398.6085 & 19.11 \\
\hline & & $38-43$ & NITVPD & 657.3334 & 12.04 \\
\hline & \multirow{2}{*}{ Asn83 } & $73-117$ & $\begin{array}{l}\text { AVLRGQALLVNSSQPWEPLQLHV } \\
\text { DKAVSGLRSLTTLLRALGAQKE }\end{array}$ & 4862.7247 & 48.37 \\
\hline & & $73-104$ & $\begin{array}{l}\text { AVLRGQALLVNSSQPWEPLQLHV } \\
\text { DKAVSGLRS }\end{array}$ & 3467.9001 & 41.63 \\
\hline & \multirow{3}{*}{ Ser126 } & $118-136$ & AISPPDAASAAPLRTITAD & 1836.9581 & 29.13 \\
\hline & & $118-146$ & $\begin{array}{l}\text { AISPPDAASAAPLRTITADTFRKLF } \\
\text { RVYS }\end{array}$ & 3134.6877 & 39.56 \\
\hline & & $118-159$ & $\begin{array}{l}\text { AISPPDAASAAPLRTITADTFRKLF } \\
\text { RVYSNFLRGKLKLYTGE }\end{array}$ & 4654.5388 & 48.18 \\
\hline \multirow{6}{*}{ Trypsin } & \multirow{2}{*}{ Asn24 } & $21-29$ & EAENITTGC* & 979.4281 & 7.65 \\
\hline & & $21-33$ & EAENITTGC**AEHC* & 1505.6603 & 10.47 \\
\hline & \multirow{2}{*}{ Asn38 } & $34-45$ & SLNENITVPDTK & 1329.6776 & 19.95 \\
\hline & & $30-45$ & AEHC**SLNENITVPDTK & 1855.9098 & 17.95 \\
\hline & Asn83 & $77-97$ & GQALLVNSSQPWEPLQLHVDK & 2358.2332 & 39.11 \\
\hline & S126 & $117-131$ & EAISPPDAASAAPLR & 1464.7573 & 25.82 \\
\hline
\end{tabular}

+ Iodoacetic acid alkylation (+ 58.0055 Da)

* Aminoethylation (+ 43.0422 Da)

† Hydrophobicity values were obtained from www.protpi.ch 
Table S6: Relative abundances of rhEPO glycopeptide cleavage products.

\begin{tabular}{|c|c|c|c|c|}
\hline Protease & Peptide & Glycosylation site & Mean (\%)* & STD (\%) \\
\hline \multirow{6}{*}{ Trypsin } & Glu21-Cys29 & \multirow{2}{*}{ Asn24 } & 90.9 & 2.2 \\
\hline & Glu21-Cys33 & & 9.1 & 2.2 \\
\hline & Ser34-Lys45 & \multirow{2}{*}{ Asn38 } & 89.5 & 0.2 \\
\hline & Ala30-Lys45 & & 10.5 & 0.2 \\
\hline & Gly77-Lys97 & Asn83 & 100.0 & 0.0 \\
\hline & Glu117-Lys97 & Ser126 & 100.0 & 0.0 \\
\hline \multirow{11}{*}{ GluC } & Ala22-Glu31 & \multirow{2}{*}{ Asn24 } & 87.3 & 1.2 \\
\hline & Ala19-Glu31 & & 12.7 & 1.2 \\
\hline & His32-Glu55 & \multirow{4}{*}{ Asn38 } & 86.7 & 0.5 \\
\hline & Asn38-Glu55 & & 10.0 & 0.2 \\
\hline & His32-Asp43 & & 3.1 & 0.5 \\
\hline & Asn38-Asp43 & & 0.3 & 0.1 \\
\hline & Ala73-Glu117 & \multirow{2}{*}{ Asn83 } & 75.5 & 1.1 \\
\hline & Ala73-Ser104 & & 24.5 & 1.1 \\
\hline & Ala118-Asp136 & \multirow{3}{*}{ Ser126 } & 29.2 & 0.1 \\
\hline & Ala118-Ser146 & & 69.3 & 0.1 \\
\hline & Ala118-Glu159 & & 1.6 & 0.2 \\
\hline
\end{tabular}

* Relative abundances were calculated as fraction of the overall intensities of peptide moieties for each glycosylation site. For this purpose, a subset of analytes was selected, which were present in all cleavage products. For $N$ glycopeptides, peak areas of H7N6F1S2, H7N6F1S3 and H7N6F1S4 were summed. For $O$-glycopeptides, H1N1S1 and H1N1S2 were summed. 
Table S7: $N$ - and $O$-glycoforms assigned in the tryptic rhEPO digest on different

glycosylation sites. All analytes were curated and quantified in LacyTools.

\begin{tabular}{|c|c|c|c|c|c|c|c|c|}
\hline \multicolumn{9}{|l|}{$\mathrm{N}$-Glycoforms } \\
\hline \multirow[t]{2}{*}{ Composition } & \multirow[t]{2}{*}{$\begin{array}{l}\text { Glycan mass } \\
\text { (Da) }\end{array}$} & \multirow[t]{2}{*}{$\begin{array}{l}\text { Literature/ } \\
\text { comment }\end{array}$} & \multicolumn{2}{|c|}{$\begin{array}{l}\text { Asn24 } \\
\text { (979.4281 Da) }\end{array}$} & \multicolumn{2}{|c|}{$\begin{array}{l}\text { Asn38 } \\
\text { (1329.6776 Da) }\end{array}$} & \multicolumn{2}{|c|}{$\begin{array}{l}\text { Asn83 } \\
\text { (1855.9098 Da) }\end{array}$} \\
\hline & & & $\begin{array}{l}\text { Mean } \\
(\%)\end{array}$ & \begin{tabular}{|l|} 
STD \\
$(\%)$ \\
\end{tabular} & $\begin{array}{l}\text { Mean } \\
(\%)\end{array}$ & $\begin{array}{l}\text { STD } \\
(\%) \\
\end{array}$ & $\begin{array}{l}\text { Mean } \\
(\%)\end{array}$ & $\begin{array}{l}\text { STD } \\
(\%)\end{array}$ \\
\hline H4N2P1 & 1134.3363 & 3 & 0.4 & 0.1 & - & - & - & - \\
\hline H5N2P1 & 1296.3892 & 3-5 & 3.6 & 1.5 & 0.2 & 0.01 & - & - \\
\hline H6N2P1 & 1458.4420 & 3-5 & 5.7 & 2.6 & 0.3 & 0.07 & - & - \\
\hline H4N2F1P1 & 1280.3942 & 3 & 0.2 & 0.1 & - & - & - & - \\
\hline H5N2F1P1 & 1442.4471 & 3 & 0.3 & 0.1 & - & - & - & - \\
\hline H6N3P1 & 1661.5214 & $(5)$ & 0.1 & 0.02 & - & - & - & - \\
\hline H6N3F1S1 & 2018.7084 & $(5)$ & 0.01 & 0.003 & 0.004 & 0.0002 & - & - \\
\hline H7N3F1P1 & 1969.6321 & (5) Fig. S14A & - & - & 0.1 & 0.02 & - & - \\
\hline H7N3F1S1 & 2180.7612 & $(5)$ & 0.02 & 0.01 & 0.2 & 0.1 & - & - \\
\hline H7N3F1S1P1 & 2260.7275 & 5 & 0.3 & 0.1 & - & - & - & - \\
\hline H4N4F1S1 & 1897.6821 & $(6)$ & 0.1 & 0.1 & - & - & - & - \\
\hline H4N5F1S1 & 2100.7615 & $(6)$ & - & - & 0.02 & 0.003 & - & - \\
\hline H5N4F1 & 1768.6395 & 5,7 & 0.3 & 0.03 & - & - & - & - \\
\hline H5N4F1S1 & 2059.7349 & 3-5 & 3.7 & 1.8 & 0.1 & 0.03 & 0.04 & 0.02 \\
\hline H5N4F1S1Ac2 & 2143.7561 & $(3-5)$ & 0.03 & 0.01 & - & - & - & - \\
\hline H5N4F1S1G1 & 2366.8252 & $(3-5)$ & 0.2 & 0.1 & - & - & - & - \\
\hline H5N4F1S2 & 2350.8303 & $3-5,7$ & 12.0 & 4.9 & 0.3 & 0.01 & 0.5 & 0.1 \\
\hline H5N4F1S2Ac1 & 2392.8409 & 3-5 & 1.1 & 0.1 & - & - & - & - \\
\hline H5N4F1S2Ac2 & 2434.8515 & 3 & 0.3 & 0.1 & - & - & - & - \\
\hline H5N4F1S2Ac3 & 2476.8621 & $(3)$ & 0.03 & 0.02 & - & - & - & - \\
\hline H5N4F1S3 & 2641.9258 & 4,5 & 0.5 & 0.1 & - & - & - & - \\
\hline H5N4F1S3Ac1 & 2683.9364 & $(4,5)$ & 0.1 & 0.01 & - & - & - & - \\
\hline H5N4F1S3Ac2 & 2725.9470 & $(4,5)$ & 0.02 & 0.01 & - & - & - & - \\
\hline H5N5F1S1G1/H6N5S2 & 2569.9046 & $(4,6,7)$ & - & - & 0.03 & 0.002 & - & - \\
\hline H5N4S2 & 2204.7724 & $(4,6,7)$ & 0.02 & 0.01 & - & - & - & - \\
\hline H6N4F1S2 & 2512.8832 & $(6)$ & 0.2 & 0.02 & - & - & - & - \\
\hline H6N5F1 & 2133.7717 & 7 & 0.1 & 0.02 & - & - & 0.1 & 0.01 \\
\hline H6N5F1S1 & 2424.8671 & $3-5,7$ & 1.6 & 0.5 & 0.4 & 0.02 & 0.8 & 0.1 \\
\hline H6N5F1S1Ac1 & 2466.8777 & $(3-5,7)$ & 0.1 & 0.003 & - & - & 0.1 & 0.01 \\
\hline H6N5F1S1Ac2 & 2508.8883 & $(3-5)$ & - & - & - & - & 0.01 & 0.002 \\
\hline H6N5F1S2 & 2715.9625 & $3-5,7,8$ & 7.7 & 0.9 & 1.8 & 0.1 & 5.7 & 0.7 \\
\hline H6N5F1S2Ac1 & 2757.9731 & 4 & 0.5 & 0.1 & 0.2 & 0.01 & 0.4 & 0.01 \\
\hline H6N5F1S2Ac2 & 2799.9837 & 3 & 0.1 & 0.04 & - & - & 0.2 & 0.03 \\
\hline H6N5F1S3 & 3007.0580 & $4,7,8$ & 9.9 & 1.0 & 5.04 & 0.4 & 6.5 & 0.2 \\
\hline H6N5F1S3Ac1 & 3049.0686 & $4,5,8$ & 1.7 & 0.08 & 0.8 & 0.01 & 1.2 & 0.1 \\
\hline H6N5F1S3Ac2 & 3091.0792 & 4,8 & 1.0 & 0.1 & 0.2 & 0.01 & 0.5 & 0.04 \\
\hline H6N5F1S3Ac3 & 3133.0898 & 8 & 0.1 & 0.03 & - & - & - & - \\
\hline H5N5F1S2G1/H6N5S3 & 2861.0001 & 4 & - & - & - & - & 0.1 & 0.01 \\
\hline H6N5F1S4 & 3298.1534 & 4 & 0.3 & 0.1 & - & - & - & - \\
\hline H6N5F1S4Ac1 & 3340.1640 & $(4)$ & 0.1 & 0.01 & - & - & - & - \\
\hline H6N5F1S4Ac2 & 3382.1746 & $(4)$ & 0.03 & 0.02 & - & - & - & - \\
\hline H6N6F1S1 & 2627.9465 & 5 & - & - & - & - & 0.01 & 0.001 \\
\hline H6N6F1S2 & 2919.0419 & 4 & 0.1 & 0.003 & 0.1 & 0.01 & 0.1 & 0.01 \\
\hline H6N6F1S3 & 3210.1373 & 3-5 & 0.03 & 0.002 & 0.2 & 0.02 & - & - \\
\hline H6N6F1S1G1/H7N6S2 & 2935.0368 & $(4,6,6)$ & - & - & 0.03 & 0.001 & - & - \\
\hline H7N6F1 & 2498.9039 & 7 & - & - & - & - & 0.1 & 0.01 \\
\hline H7N6F1S1 & 2789.9993 & 3-5 & 0.8 & 0.2 & 0.9 & 0.1 & 1.0 & 0.1 \\
\hline H7N6F1S1Ac1 & 2832.0099 & $(3-5)$ & - & - & 0.02 & 0.003 & 0.1 & 0.01 \\
\hline H7N6F1S2 & 3081.0947 & $4,5,7,8$ & 4.6 & 0.1 & 7.2 & 0.4 & 7.8 & 0.6 \\
\hline H7N6F1S2Ac1 & 3123.1053 & 8 & 0.3 & 0.1 & 0.8 & 0.02 & 1.0 & 0.1 \\
\hline H7N6F1S2Ac2 & 3165.1159 & $(8)$ & 0.1 & 0.03 & 0.1 & 0.01 & 0.3 & 0.02 \\
\hline H7N6F2S2 & 3227.1526 & $(4,6)$ & - & - & 0.04 & 0.0001 & 0.1 & 0.002 \\
\hline H7N6F1S3 & 3372.1902 & $3-5,7,8$ & 13.5 & 0.9 & 22.7 & 1.4 & 19.9 & 0.7 \\
\hline H7N6F1S3Ac1 & 3414.2008 & $3-5,8$ & 1.7 & 0.6 & 5.1 & 0.4 & 4.9 & 0.02 \\
\hline H7N6F1S3Ac2 & 3456.2114 & $3,4,8$ & 0.5 & 0.2 & 2.1 & 0.03 & 2.0 & 0.01 \\
\hline H7N6F1S3Ac3 & 3498.2220 & 4,8 & - & - & - & - & 0.5 & 0.003 \\
\hline
\end{tabular}


Continuation Table S7:

\begin{tabular}{|c|c|c|c|c|c|c|c|c|}
\hline \multicolumn{9}{|l|}{$N$-Glycoforms } \\
\hline \multirow[t]{2}{*}{ Composition } & \multirow[t]{2}{*}{$\begin{array}{l}\text { Glycan mass } \\
\text { (Da) }\end{array}$} & \multirow[t]{2}{*}{$\begin{array}{l}\text { Literature/ } \\
\text { comment }\end{array}$} & \multicolumn{2}{|c|}{$\begin{array}{l}\text { Asn24 (979.4281 } \\
\text { Da) }\end{array}$} & \multicolumn{2}{|c|}{$\begin{array}{l}\text { Asn38 } \\
\text { (1329.6776 Da) }\end{array}$} & \multicolumn{2}{|c|}{$\begin{array}{l}\text { Asn83 } \\
\text { (1855.9098 Da) }\end{array}$} \\
\hline & & & $\begin{array}{l}\text { Mean } \\
(\%)\end{array}$ & $\begin{array}{l}\text { STD } \\
(\%)\end{array}$ & $\begin{array}{l}\text { Mean } \\
(\%)\end{array}$ & $\begin{array}{l}\text { STD } \\
(\%)\end{array}$ & $\begin{array}{l}\text { Mean } \\
(\%)\end{array}$ & $\begin{array}{l}\text { STD } \\
(\%)\end{array}$ \\
\hline H7N6F1S3Ac4 & 3540.2326 & 8 & - & - & 0.1 & 0.004 & 0.2 & 0.004 \\
\hline H7N6F1S3G1 & 3679.2805 & 4,5 & - & - & 0.2 & 0.1 & - & - \\
\hline H6N6F1S2G1/H7N6S3 & 3226.1322 & 4 & - & - & 0.03 & 0.002 & - & - \\
\hline H7N6F1S4 & 3663.2856 & $3-5,7,8$ & 7.2 & 0.8 & 15.2 & 0.1 & 8.9 & 0.6 \\
\hline H7N6F1S4Ac1 & 3705.2962 & $3-5,7,8$ & 2.2 & 0.3 & 5.0 & 0.3 & 2.3 & 0.2 \\
\hline H7N6F1S4Ac2 & 3747.3068 & $3,4,7,8$ & 0.9 & 0.6 & 2.5 & 0.1 & 1.4 & 0.1 \\
\hline H7N6F1S4Ac3 & 3789.3174 & $5,7,8$ & 0.2 & 0.1 & 0.4 & 0.01 & - & - \\
\hline H7N6F1S4Ac4 & 3831.3280 & 7,8 & 0.1 & 0.1 & 0.4 & 0.02 & - & - \\
\hline H7N6F1S4Ac5 & 3873.3386 & 7,8 & 0.02 & 0.02 & 0.1 & 0.01 & - & - \\
\hline H7N6F1S4Ac6 & 3915.3492 & 7,8 & - & - & 0.1 & 0.01 & - & - \\
\hline H7N6F1S5 & 3954.3810 & 4,5 & 0.1 & 0.04 & - & - & - & - \\
\hline H7N6F1S5Ac1 & 3996.3916 & $(4,5)$ & 0.01 & 0.01 & - & - & - & - \\
\hline H7N7F1S2 & 3284.1741 & $(6)$ & 0.02 & 0.001 & 0.1 & 0.001 & 0.02 & 0.002 \\
\hline H7N7F1S3 & 3575.2695 & $(6)$ & - & - & 0.1 & 0.003 & - & - \\
\hline H8N7F1S1 & 3155.1315 & $(3,5,8)$ & 0.2 & 0.4 & 0.2 & 0.02 & 0.4 & 0.02 \\
\hline H8N7F1S1Ac1 & 3197.1421 & $(3,5,8)$ & - & - & - & - & 0.02 & 0.001 \\
\hline H8N7F1S2 & 3446.2269 & $3,5,8$ & 1.9 & 0.1 & 3.1 & 0.01 & 3.3 & 0.1 \\
\hline H8N7F1S2Ac1 & 3488.2375 & $(3,5,8)$ & 0.1 & 0.04 & - & - & 0.4 & 0.02 \\
\hline H8N7F1S2Ac2 & 3530.2481 & $(3,5,8)$ & 0.02 & 0.003 & - & - & - & - \\
\hline H8N7F1S3 & 3737.3224 & $3-5,7,8$ & 6.3 & 1.1 & 8.5 & 0.2 & 8.6 & 0.5 \\
\hline H8N7F1S3Ac1 & 3779.3330 & 4,8 & 0.5 & 0.2 & 1.4 & 0.1 & 2.0 & 0.1 \\
\hline H8N7F1S3Ac2 & 3821.3436 & $3-5,8$ & 0.1 & 0.1 & 0.3 & 0.02 & 0.9 & 0.04 \\
\hline H8N7F1S3Ac3 & 3863.3542 & $(3-5,8)$ & - & - & 0.1 & 0.01 & 0.2 & 0.01 \\
\hline H8N7F2S3 & 3883.3803 & $(4,6)$ & - & - & 0.1 & 0.02 & - & - \\
\hline H8N9F1S3 & 4143.4811 & $(6)$ & - & - & - & - & 0.2 & 0.01 \\
\hline H8N7F1S4 & 4028.4178 & $3-5,7,8$ & 3.7 & 0.9 & 8.4 & 0.9 & 6.4 & 0.6 \\
\hline H8N7F1S4Ac1 & 4070.4284 & 4,8 & 1.0 & 0.1 & 1.9 & 0.2 & 1.9 & 0.2 \\
\hline H8N7F1S4Ac2 & 4112.4390 & 4,8 & 0.4 & 0.2 & 0.9 & 0.04 & 0.9 & 0.1 \\
\hline H8N7F1S4Ac3 & 4154.4496 & 8 & 0.1 & 0.04 & 0.3 & 0.02 & 0.4 & 0.02 \\
\hline H8N7F1S4Ac4 & 4196.4602 & 8 & - & - & 0.2 & 0.01 & 0.1 & 0.002 \\
\hline H8N7F1S4Ac5 & 4238.4708 & 8 & - & - & 0.1 & 0.01 & 0.1 & 0.003 \\
\hline H8N7F1S5 & 4319.5132 & 4 & 0.04 & 0.03 & - & - & - & - \\
\hline H9N8F1S1 & 3520.2637 & $(3,5)$ & - & - & - & - & 0.1 & 0.01 \\
\hline H9N8F1S1Ac1 & 3562.2743 & $(3,5)$ & - & - & - & - & 0.01 & 0.0004 \\
\hline H9N8F1S2 & 3811.3591 & 3,5 & 0.4 & 0.02 & 0.3 & 0.01 & 1.0 & 0.02 \\
\hline H9N8F1S3 & 4102.4545 & $3-5,7,8$ & 1.0 & 0.4 & 1.5 & 0.03 & 2.9 & 0.1 \\
\hline H9N8F1S3Ac1 & 4144.4651 & $(3-5,7,8)$ & 0.04 & 0.01 & 0.2 & 0.04 & 0.4 & 0.02 \\
\hline H9N8F1S3Ac2 & 4186.4757 & $(3-5,7,8)$ & 0.02 & 0.01 & - & - & 0.1 & 0.003 \\
\hline H9N8F1S4 & 4393.5500 & $3-5,7,8$ & 0.4 & 0.02 & 0.1 & 0.01 & 2.3 & 0.5 \\
\hline H9N8F1S4Ac1 & 4435.5606 & $4,5,8$ & 0.1 & 0.01 & - & - & 0.4 & 0.1 \\
\hline H9N8F1S4Ac2 & 4477.5712 & 8 & 0.03 & 0.01 & - & - & 0.2 & 0.02 \\
\hline H10N9F1S1 & 3885.3959 & $(3-5,8)$ & - & - & - & - & 0.02 & 0.001 \\
\hline H10N9F1S2 & 4176.4913 & $(3-5,8)$ & - & - & - & - & 0.1 & 0.003 \\
\hline H10N9F1S4 & 4758.6822 & $3-5,8$ & 0.1 & 0.03 & - & - & 0.2 & 0.04 \\
\hline \multicolumn{5}{|l|}{$O$-Glycoforms } & & & & \\
\hline \multirow[t]{2}{*}{ Composition } & \multirow[t]{2}{*}{$\begin{array}{l}\text { Glycan mass } \\
\text { (Da) }\end{array}$} & \multirow[t]{2}{*}{$\begin{array}{l}\text { Literature/ } \\
\text { comment }\end{array}$} & \multicolumn{2}{|c|}{$\begin{array}{l}\text { Ser126 } \\
(1464.7573 \mathrm{Da})\end{array}$} & & & & \\
\hline & & & $\begin{array}{l}\text { Mean } \\
(\%)\end{array}$ & $\begin{array}{l}\text { STD } \\
(\%)\end{array}$ & & & & \\
\hline N1 & 203.0794 & 9 & 1.7 & 0.3 & & & & \\
\hline N1S1 & 494.1748 & 9 & 0.8 & 0.1 & & & & \\
\hline N1S1Ac1 & 536.1854 & $(9)$ & 0.1 & 0.01 & & & & \\
\hline N1S1Ac2 & 578.1960 & $(9)$ & 0.01 & 0.0003 & & & & \\
\hline H1N1 & 365.1322 & $7-9$ & 1.5 & 0.2 & & & & \\
\hline H1N1S1 & 656.2276 & $7-9$ & 48.0 & 2.8 & & & & \\
\hline H1N1S1Ac1 & 698.2382 & $7,8,10$ & 1.8 & 0.1 & & & & \\
\hline H1N1S1Ac2 & 740.2488 & 7,8 & 0.4 & 0.03 & & & & \\
\hline H1N1G1 & 672.2225 & 10 & 0.2 & 0.04 & & & & \\
\hline
\end{tabular}


Continuation Table S7:

\begin{tabular}{|c|c|c|c|c|}
\hline \multicolumn{5}{|l|}{$\mathrm{O}$-Glycoforms } \\
\hline \multirow[t]{2}{*}{ Composition } & \multirow[t]{2}{*}{ Mass (Da) } & \multirow[t]{2}{*}{$\begin{array}{l}\text { Literature/ } \\
\text { comment }\end{array}$} & \multicolumn{2}{|c|}{$\begin{array}{l}\text { Ser126 } \\
(1464.7573 \mathrm{Da})\end{array}$} \\
\hline & & & $\begin{array}{l}\text { Mean } \\
(\%)\end{array}$ & $\begin{array}{l}\text { STD } \\
(\%)\end{array}$ \\
\hline H1N1G1Ac1 & 714.2331 & $\begin{array}{l}\left({ }^{10}\right) \text { Fig. } \\
\text { S14B }\end{array}$ & 0.01 & 0.002 \\
\hline H1N1S2 & 947.3230 & $7-9$ & 42.2 & 2.2 \\
\hline H1N1S2Ac1 & 989.3336 & 7,8 & 2.3 & 0.4 \\
\hline H1N1S2Ac2 & 1031.3442 & 7,8 & 0.3 & 0.1 \\
\hline H1N1S2Ac3 & 1073.3548 & 7 & 0.1 & 0.01 \\
\hline H1N1S2Ac4 & 1115.3654 & 7 & 0.1 & 0.01 \\
\hline H1N1S1G1 & 963.3179 & 10 & 0.5 & 0.01 \\
\hline H1N1S1G1Ac1 & 1005.3285 & $\begin{array}{l}\text { (7-10) Fig. } \\
\text { S14C }\end{array}$ & 0.1 & 0.01 \\
\hline H1N1S3 & 1238.4184 & $\begin{array}{l}\text { (7-9) Fig. } \\
\text { S14D }\end{array}$ & 0.1 & 0.004 \\
\hline H2N1 & 527.1850 & $(11)$ & 0.003 & 0.0004 \\
\hline H2N1S1 & 818.2804 & $(11)$ & 0.01 & 0.001 \\
\hline
\end{tabular}

() in line with biosynthetic pathways of referenced structures, but, to our knowledge not previously reported for $\mathrm{CHO}$ cell produced rhEPO

Table S8: Overview of the detected non-glycosylated variants of rhEPO glycosylation sites.

\begin{tabular}{|c|c|c|c|c|}
\hline \multirow[t]{2}{*}{ Glycosylation site } & \multicolumn{2}{|l|}{ Trypsin } & \multicolumn{2}{|l|}{ GluC } \\
\hline & Peptide & Mean* \pm STD (\%) & Peptide & Mean* \pm STD (\%) \\
\hline \multirow[t]{3}{*}{ Asn24 } & Glu21-Cys29 & $2.3 \pm 0.6$ & Asn24-Glu31† & n.q. \\
\hline & \multirow[t]{2}{*}{ Glu21-Cys33 } & \multirow[t]{2}{*}{ n.q. } & Ala22-Glu31 & $2.0 \pm 0.2$ \\
\hline & & & Ala19-Glu31 & n.d. \\
\hline \multirow[t]{4}{*}{ Asn38 } & \multirow[t]{2}{*}{ Ser34-Lys45 } & \multirow[t]{2}{*}{$0.001 \pm 0.0001$} & His31-Glu55 & n.d. \\
\hline & & & Asn38-Glu55 & $1.2 \pm 0.03$ \\
\hline & \multirow[t]{2}{*}{ Ala30-Lys45 } & \multirow[t]{2}{*}{ n.d. } & His32-Asp43 & n.d. \\
\hline & & & Asn38-Asp43 & n.q. \\
\hline \multirow[t]{2}{*}{ Asn83 } & \multirow[t]{2}{*}{ Gly77-Lys97 } & \multirow[t]{2}{*}{ n.d. } & Ala73-Glu117 & n.d. \\
\hline & & & Ala73-Ser104 & n.d. \\
\hline \multirow[t]{3}{*}{ Ser126 } & \multirow[t]{3}{*}{ Glu117-Arg131 } & \multirow[t]{3}{*}{$5.1 \pm 1.0$} & Ala118-Asp136 & $6.3 \pm 0.04$ \\
\hline & & & Ala118-Ser146 & $2.0 \pm 0.03$ \\
\hline & & & Ala118-Glu159 & n.d. \\
\hline
\end{tabular}

† no glycopeptides detected, n.q. = not quantified, n.d. = not detected

* Relative abundances were calculated as fraction of the summed overall intensities of all main glycoforms, which were analyzed in Skyline (Figure 2) for each glycosylation site. 
Table S9: Overview of tryptic peptide moieties used for the relative quantification of Asn47 deamidation, Met54 oxidation and Asn147 deamidation.

\begin{tabular}{|l|l|l|l|}
\hline Site & Peptide & Mean (\%) & STD (\%) \\
\hline Asn47 & VN[+1]FYAWK & 4.9 & 0.1 \\
\hline Met54 & M[+16]EVGQQAVEVWQGLALLSEAVLR & 1.5 & 0.1 \\
\hline Asn147 & VYSN[+1]FLR & 5.3 & 0.1 \\
\hline
\end{tabular}

\section{S-4 References}

1. Serra, A.; Hemu, X.; Nguyen, G. K.; Nguyen, N. T.; Sze, S. K.; Tam, J. P., A high-throughput peptidomic strategy to decipher the molecular diversity of cyclic cysteine-rich peptides. Sci Rep 2016, 6, 23005.

2. Ni, W.; Dai, S.; Karger, B. L.; Zhou, Z. S., Analysis of Isoaspartic Acid by Selective Proteolysis with Asp-N and Electron Transfer Dissociation Mass Spectrometry. Anal. Chem. 2010, 82 (17), 7485-7491.

3. Thomson, R. I.; Gardner, R. A.; Strohfeldt, K.; Fernandes, D. L.; Stafford, G. P.; Spencer, D. I.; Osborn, H. M., Analysis of three epoetin alpha products by LC and LC-MS indicates differences in glycosylation critical quality attributes, including sialic acid content. Anal. Chem. 2017, 89 (12), 6455-6462.

4. Falck, D.; Haberger, M.; Plomp, R.; Hook, M.; Bulau, P.; Wuhrer, M.; Reusch, D., Affinity purification of erythropoietin from cell culture supernatant combined with MALDI-TOF-MS analysis of erythropoietin N-glycosylation. Sci Rep 2017, 7 (1), 5324.

5. Szabo, Z.; Thayer, J. R.; Reusch, D.; Agroskin, Y.; Viner, R.; Rohrer, J.; Patil, S. P.; Krawitzky, M.; Huhmer, A.; Avdalovic, N., High performance anion exchange and hydrophilic interaction liquid chromatography approaches for comprehensive mass spectrometry-based characterization of the $\mathrm{N}$-glycome of a recombinant human erythropoietin. J. Proteome Res. 2018, 17 (4), 1559-1574.

6. Yang, G.; Hu, Y.; Sun, S.; Ouyang, C.; Yang, W.; Wang, Q.; Betenbaugh, M.; Zhang, H., Comprehensive Glycoproteomic Analysis of Chinese Hamster Ovary Cells. Anal. Chem. 2018, 90 (24), 14294-14302.

7. Stübiger, G.; Marchetti, M.; Nagano, M.; Grimm, R.; Gmeiner, G.; Reichel, C.; Allmaier, G., Characterization of $\mathrm{N}$-and $\mathrm{O}$-glycopeptides of recombinant human erythropoietins as potential biomarkers for doping analysis by means of microscale sample purification combined with MALDI-TOF and quadrupole IT/RTOF mass spectrometry. J Sep Sci 2005, 28 (14), 1764-1778.

8. Takegawa, Y.; Ito, H.; Keira, T.; Deguchi, K.; Nakagawa, H.; Nishimura, S. I., Profiling of N-and O-glycopeptides of erythropoietin by capillary zwitterionic type of hydrophilic interaction chromatography/electrospray ionization mass spectrometry. J Sep Sci 2008, 31 (9), 1585-1593. 9. Byeon, J.; Lim, Y.-R.; Kim, H.-H.; Suh, J.-K., Structural Identification of a Non-Glycosylated Variant at Ser126 for O-Glycosylation Site from EPO BRP, Human Recombinant Erythropoietin by LC/MS Analysis. Mol Cells 2015, 38 (6), 496-505.

10. Yang, Y.; Liu, F.; Franc, V.; Halim, L. A.; Schellekens, H.; Heck, A. J., Hybrid mass spectrometry approaches in glycoprotein analysis and their usage in scoring biosimilarity. Nat Commun 2016, 7, 13397.

11. van Diepen, A.; van der Plas, A. J.; Kozak, R. P.; Royle, L.; Dunne, D. W.; Hokke, C. H., Development of a Schistosoma mansoni shotgun O-glycan microarray and application to the discovery of new antigenic schistosome glycan motifs. International journal for parasitology 2015, 45 (7), 465-75. 